\title{
An analytical cost estimation model for the design of axisymmetric components with open-die forging technology
}

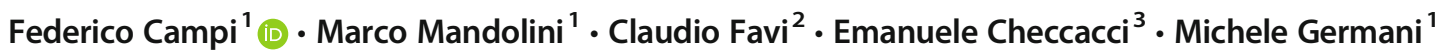

Received: 26 March 2020 / Accepted: 17 August 2020 / Published online: 29 August 2020

(C) The Author(s) 2020

\begin{abstract}
Open-die forging is a manufacturing process commonly used for realising simple shaped components with high mechanical performances and limited capability in terms of production volume. To date, an analytical model for estimating the costs of components manufactured with this technology is still an open issue. The paper aims to define an analytical model for cost estimation of axisymmetric components manufactured by open-die forging technology. The model is grounded on the analysis of geometrical features available at the design stage providing a detailed cost breakdown in relation to all the process phases and the raw material. The model allows predicting product cost, linking geometrical features and cost items, to carry out design-to-cost actions oriented to the reduction of manufacturing cost. The model is mainly conceived for design engineers, cost engineers and buyers, respectively, for improving the product design, the manufacturing process and the supply chain. Cost model and related schemas for collecting equations and data are presented, including the approach for sizing the raw material and a set of rules for modelling the related cost. Finally, analytic equations for modelling the cost of the whole forging process (i.e. billet cutting, heating, pre-smoothing, smoothing, upsetting, max-shoulder cogging, necking and shoulders cogging) are reported. The cost model has been tested on eight cylindrical parts such as discs and shafts with different shapes, dimensions and materials. Two forge masters have been involved in the testing phase. The absolute average deviation between the actual and estimated costs is approximately $4 \%$ for raw material and $21 \%$ for the process. The absolute average deviation on the total cost (raw material and manufacturing process) is approximately $5 \%$.
\end{abstract}

Keywords Hot forging $\cdot$ Cost estimation $\cdot$ Open-die forging $\cdot$ Cost model $\cdot$ Design features $\cdot$ Manufacturing parameters · Design-to-cost

Federico Campi

f.campi@pm.univpm.it

Marco Mandolini

m.mandolini@univpm.it

Claudio Favi

claudio.favi@unipr.it

Emanuele Checcacci

emanuele1.checcacci@bakerhughes.com

Michele Germani

m.germani@univpm.it

1 Università Politecnica delle Marche, Via Brecce Bianche 12, 60131 Ancona, Italy

2 Università di Parma, Parco Area Delle Scienze 181/A, 43121 Parma, Italy

3 Baker Hughes, Via Felice Matteucci 2, 50127 Florence, Italy

\section{Introduction and state-of-art}

Forging is a manufacturing process that shapes a billet, or an ingot, by applying compressive forces on it. The process temperature, employed during forging operations, classifies the technology in hot forging and cold forging [27]. Another typical aspect of this process is the use of hammers or presses to squeeze and deform the material into a high strength part. The deformation could be achieved using flat or simple dies that do not completely enclose the material or into complex and shaped dies. In the first case, the process configuration is called open-die forging, and in the second one, the process configuration is called closed die forging. The open-die forging process can be divided into various phases, as shown in Fig. 1.

The open-die forging process is commonly used for medium-high heavy components (from few kilogrammes to several tons), realised in small batches (from one to few 
Fig. 1 Manufacturing process steps for axisymmetric forging pieces

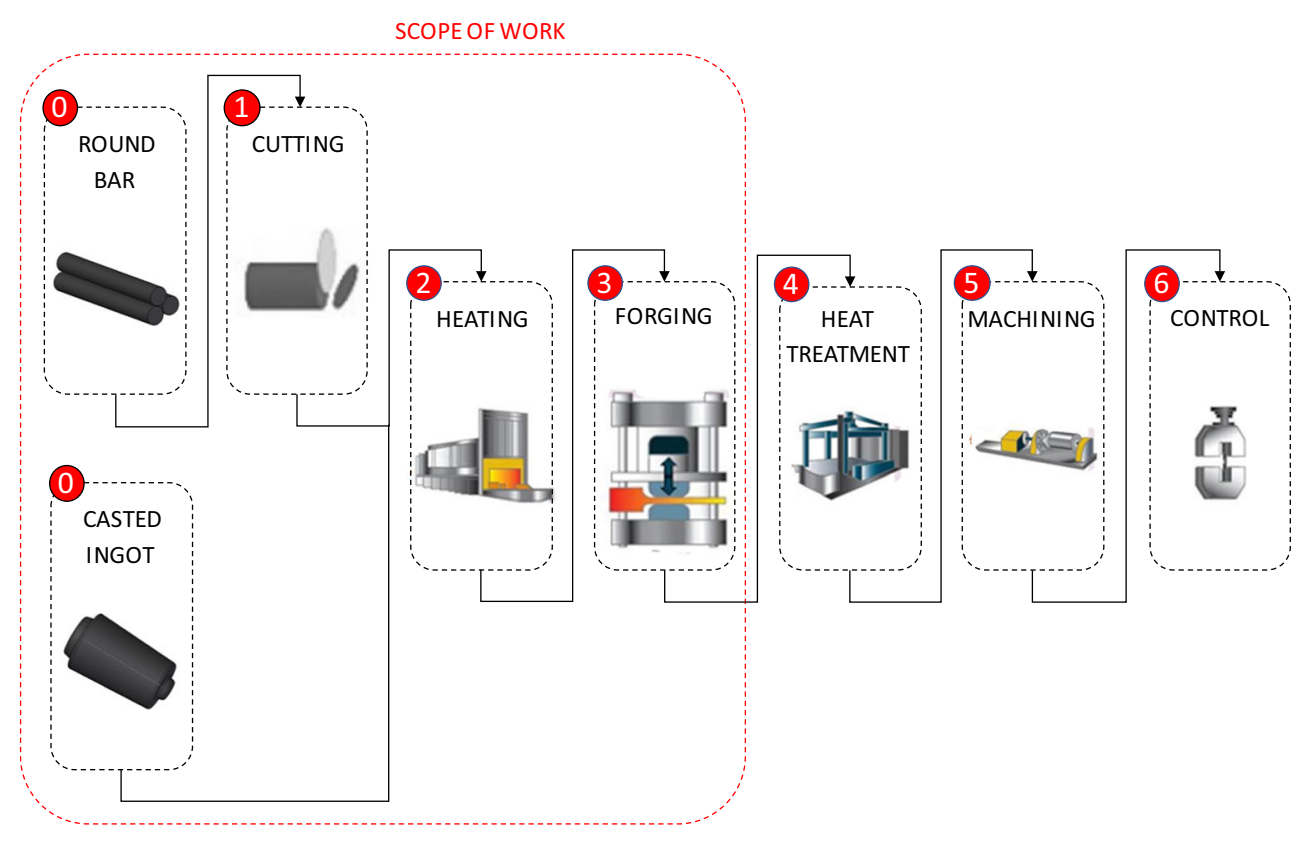

dozens of pieces). This process does not require complex shaped dies as for closed die forging, while simple tools, such as flat or round dies and blades, are generally used. The economic value of such components is generally high since the high raw material rate and energy consumption. For these reasons, it is crucial to estimate the production cost in the early phases of the engineering design process. The design of opendie forged products is a long and iterative process [38]. It is well known that, although the design activity costs approximately $10 \%$ of the total budget for a new project, typically $80 \%$ of manufacturing costs are determined during the design stage [41]. A key target in product design is the cost minimisation, without preempting the desired level of quality, functionality and value [2]. During the product development process (PDP), cost plays a critical role and drives most of the technical and technological solutions [18]. Cost reduction can be achieved by adopting different strategies: cost-efficient design, improve manufacturing performance, increase suppliers' competition and delocalised production in emerging countries [46]. Cost estimation is a design task which allows evaluating the production costs before the manufacturing process, providing a classification of cost items both for the materials and the manufacturing processes [32,33]. Mathematical model is necessary to derive cost assessment, and cost items are collected together within the model by the means of mathematical function [25]. Cost estimation is considered the first step to develop the so-called design-to-cost (DtC) strategy, which aims at the reduction of product cost during the PDP [16, 19].

The methods developed for cost estimation can be grouped in two main families: (i) qualitative methods, which are based on a comparative analysis of a new product and an existing one and (ii) quantitative methods, which are based on a detailed analysis of the product design, including its features and corresponding manufacturing processes [37]. Qualitative cost estimation approaches include knowledge-based and intuitive methods, which are grounded on the estimator's experience and, analogical methods, which are based on the manufacturing process similarity between the product to be designed and previously estimated products [2]. Quantitative cost estimation approaches include analytical methods, which use geometric features as the basis for cost estimation, and parametric methods founded on the relations between product characteristics and their cost [10].

In the context of parametric methods, the scientific literature is characterised by several scientific papers aiming at applying and evaluating the performance of data mining, machine learning and artificial intelligence approaches for cost estimation during the preliminary design phases. In the past, these approaches have been developed for cost analysis in the management of complex projects, such as the development of equipment for TFT (thin-film-transistor) and LCD (liquid crystal display) monitors [10] and the creation of highways [22]. The main commonly used artificial intelligence techniques are fuzzy logic models, artificial neural networks, regression models, case-based reasoning, hybrid models, diction tree, random forest, supportive vector machine, AdaBoost, scalable boosting trees and evolutionary computing such as genetic algorithm [13]. Recently, these techniques, based on artificial intelligence, are also being used for estimating the cost of individual components of industrial products, as highlighted in Loyer et al. [26]. These methods offer promising results in the context of parametric methods for cost estimation. For example, the methodology proposed by Elmousalami [14] — scalable boosting trees (XGBoost) -allows reaching low levels of mean absolute percentage error (about 9\%) and high correlation coefficients (0.93). However, 
the use of artificial intelligence-based methods for the analytical assessment of the production cost of industrial products is still very limited [24]. The algorithms are complicated and opaque to the stakeholders (so much so that the estimator could not explain the model workings to the stakeholders in a short easily grasped elevator speech). If on the one hand, they can be beneficial during the early design stages, when a detailed production cost breakdown is not required; on the other hand, they are not accurate enough to estimate the cost of a product by simulating the production process. During the detailed planning or even during the procurement phase, it is necessary to understand the reasons that led to the determination of the cost in order to facilitate the negotiation phase with suppliers. This is the main limitation of these methods, and the reason why analytical cost models are preferable in the early stages of the design process. In the context of analytical cost estimation methods, research works are focused on defining cost models for specific manufacturing processes, such as chip metal forming [8], sheet metal [42], injection moulding [15], sand casting [11] and high pressure die casting [17]. Few attempts were made to estimate the cost of forged parts. Berlioz et al. [5] proposed a procedure for hot-forging cost estimation based on the volume of material and the required energy to deform the part. Kukhar et al. [29] used computer simulation (Deform 3D) to select the best strategy to reduce forging force and material waste in closed die forging. They added a preforming billet upsetting, which reduces the waste of metal flash up to $22 \%$, and the forging force more than four times. Bariani et al. [3] proposed a methodology for estimating the initial and maintenance costs for cold forging tools, moving the focus to the cost estimation process of forging dies [6]. However, even if the cost of tooling is one of the most impactful items in the overall component cost, other cost items (e.g. material cost, machine cost) are missing. An interesting approach has been given by Masel et al., which presented a rough cost estimation method by mean of a parametric model [31]. The parametric model provides an accurate estimate of the forging die volume based on the part's geometry, which is one of the most significant cost drivers in the manufacturing of axisymmetric parts. However, the available model for cost estimation of forged components is incomplete and not accurate (i.e. heating is missing from the estimation). Besides, each forging process (e.g. open-die, closed-die) has specific features and requires specific cost models. A lack in the assessment of manufacturing cost for open-die forging technology was observed in the state-of-art concerning the link between geometrical features, manufacturing process parameters and material properties.

Considering the advantages of using analytical cost models and the absence of such ones for the estimation of open-die forged axisymmetric components, this paper wants to cover this gap in the scientific literature. The paper attempts to define an analytical model for cost estimation of axisymmetric components manufactured by open-die forging technology. The boundary of the proposed work is limited to the forging technology (open-die forging), excluding subsequent processes (i.e. machining) which have an extensive literature in this regard $[8,44,45,20]$. The analytical model is grounded on the evaluation of geometrical features which characterise the axisymmetric part. By using the geometrical product information, the model allows providing a detailed cost breakdown considering the manufacturing phases of the open-die forging process and the material characteristics.

Based on the literature review, this is the first paper presenting an analytical cost model for the open-die forging of axisymmetric parts. The presented cost model contains equations that combine a set of different parameters belonging to three categories: (i) geometrical features of the product under design such as shape, dimensions, area and volume; (ii) manufacturing aspects of the forging process such as machine, process temperature, forces and number of strokes; and (iii) materials properties such as strain rate strength and shear stress.

The paper is structured as follows. Section 2 reports a description of the cost estimation model adopted for axisymmetric parts manufactured with open-die forging technology (materials and methods). Section 3 describes how this model can be adopted in a real case study: round discs and shafts of axial compressors (case study). Section 4 summarises the outcomes of the proposed approach (results and discussion), while Section 5 ends the paper with benefits, drawbacks and future developments in this field (conclusions).

\section{Materials and methods}

The open-die forging cost model presented in this work has been made by combining several contributions retrieved from the scientific and industrial literature, with the knowledge of expert production technologists and cost engineers. The proposed model was implemented in a specific cost analysis tool [21] and used for automatically (through geometrical features recognition algorithms) and analytically (by estimating manufacturing processes) estimating production cost of components from 3D CAD files.

The developed cost model consists of a combination of data, rules and equations organised according to the framework depicted in Fig. 2. The cost estimation process is originated from a set of features represented by the 3D CAD model of the component to be analysed. The features are (i) maximum diameter, (ii) length, (iii) volume, (iv) material, (v) general roughness, (vi) general tolerance and (vii) shape (implicitly represented by the 3D CAD model, in terms of the sequence of cylindrical spans with relative diameter and length). In addition, the production batch should be considered because it influences production set-up phases. The overall 
Fig. 2 Open-die forging cost model

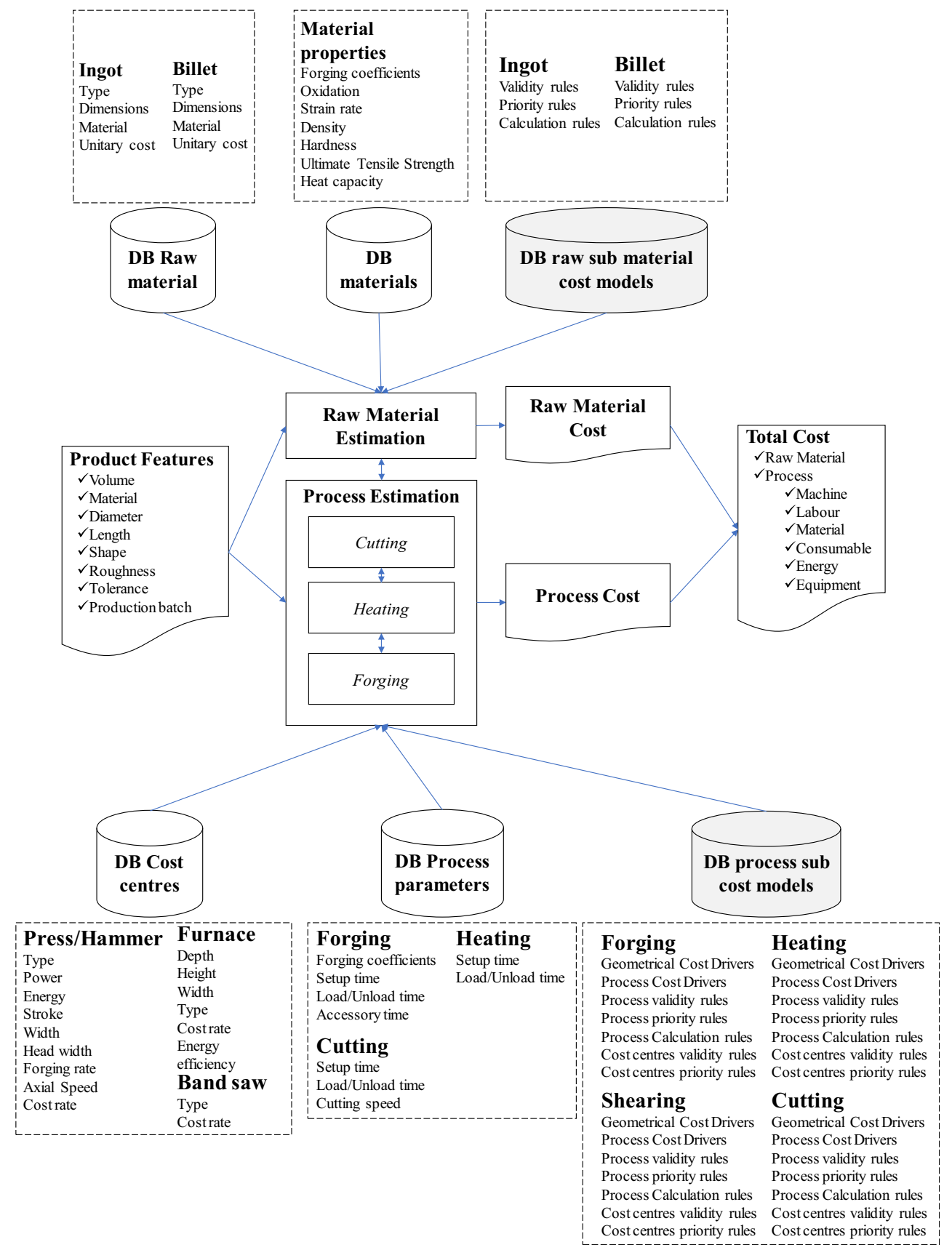

outputs of the cost model consist of raw material and process cost. The latter is commonly split into six items, according to the source of cost $[9,43,23,46]$. This organisation is a result of the literature analysis, and it reflects the cost items generally used in consolidated manufacturing technologies.

- Machine cost: cost item related to the machine (or set of machines) used for transforming a raw material in the final component (e.g. hammer, furnace);

- Labour cost: cost item related to the workforce employed during the process (e.g. workpiece loading and unloading, machine setting);
- Material cost: cost item related to those materials used or generated during the process (e.g. scraps);

- Consumable cost: cost item related to soft tools used during the process (e.g. cutting tools, lubricant);

- Energy cost: cost item related to the energy source (or set of energy sources) required by a machine, its equipment or tools (e.g. electricity, steam);

- Equipment cost: cost item related to those systems required for realising the process (e.g. fixture, jigs, dies, moulds).

Assumptions made by the authors for the open-die forging cost model are reported here below: 
- Labour, consumable and energy are accounted within the machine cost item. Indeed, the hourly rate of each cost centre accounts for all such contributions. The hourly machine rate also includes accessory items, such as the cost of cranes or forklifts needed to move the forged parts.

- Equipment (e.g. customised die) is not required for opendie forging, and then, they are not considered, because, in the open-die forging of axisymmetric components, the tools used are generally flat dies or bladed dies for specific operations (e.g. necking). Indeed, during the open-die forging operations, there is no need to change the die whenever the forging characteristic (dimensions, features, material) are changed. This is the opposite to what happens in closed die forging, where each type of component has its die.

The cost estimation process presented in this paper is based on six different repositories of knowledge and data. Three of them (raw material, material and raw material sub cost models) are mostly used for estimating the raw material cost. The raw material database is a sort of catalogue containing the set of billets and ingots used by a forging process. Materials database, instead, contains mechanical, physical and thermal properties (e.g. density, heat capacity, strain rate), required for computing those manufacturing process parameters, used for estimating the process cost of each production phase. Raw material cost models database is a repository of rules and equations used for selecting and estimating the raw material cost. Knowledge is organised in two sets: the first one is used for managing ingots and the second one is used for billets. Each cost model is defined by a list of validity rules (used to establish when using ingots or billets), priority rules (used for prioritising raw materials when both ingots and billets are valid) and calculation rules (used for sizing the raw material, compute waste and cost).

The process cost estimation is supported by three databases containing respectively cost centres, process parameters and process sub cost models. The first one is a sort of catalogue which contains the list of cost centres, with relative parameters (e.g. dimensions, power, cost rate), to be employed for a standard open-die forging process. The second one contains those parameters (e.g. forging coefficients, cutting speed) necessary for estimating the process cost. It is worth noting that such parameters are estimated according to component features, raw material and cost centres of the process phase where employed. The process sub cost models database is a repository of a structured set of information related to the auxiliary processes and their cost models. Each one is defined by a list of geometrical (related to the product features) and process (related to process parameters) cost drivers, process validity rules (used to establish when a cost model is valid), priority rules (used for prioritising cost models when two or more of them can be alternatively employed, such as the billet shearing or sawing), calculation rules (set of equations used for computing process cost drivers), cost centres validity rules and priority rules (used for selecting the cost centre to be employed for each process phase).

The overall equation used for estimating the total cost is presented in Eq. 1. It considers the cost of raw material ( $\left.C_{\text {material }}\right)$, billet cutting $\left(C_{\text {cutting }}\right)$, billet heating $\left(C_{\text {heating }}\right)$ and forging process $\left(C_{\text {forging }}\right)$. This cost model does not account the cost of other operations such as machining and heat treatments.

$C_{\text {tot }}=C_{\text {material }}+C_{\text {cutting }}+C_{\text {heating }}+C_{\text {forging }}$

The following paragraphs describe in detail each item. All the symbols used in the following paragraphs are summarised and described in Table 9.

\subsection{Raw material cost}

\subsubsection{Design of raw material}

The raw material cost of a forged component mainly depends on the weight. Often, designers do not know the shape and dimensions of the forged stock, because they are more focused on the shape and dimensions of the finished part, generally obtained with machining processes. However, for analytically estimating the raw material cost, at least a rough design is required. For axisymmetric components, like those considered in this paper, the approach presented in Fig. 3 can be used for generating a 3D CAD model for open-die forged components starting from the shape of the finished part:

1. Identify the component axis of symmetry;

2. Compute the turning profile (polyline curve) of the finished part, according to the axis of symmetry;

3. Simplify the turning profile by removing details (defeaturing). Indeed, open-die forging is not suitable for realising small details (e.g. grooves, holes, fillets) because only simple tools are employed (e.g. flat dies);

4. Offset the turning profile using a value that depends by material (the more the oxidation, the more the offset, for compensating material loss) and distance from the axis of symmetry (the more the distance, the more the offset, for ensuring uniform tolerances);

5. Simplify the axisymmetric profile established in the previous step, by considering the physical constraints of the process. For example, any cylindrical slot must have an axial extension higher than the hammer size;

6. Revolve the axisymmetric profile, created in the previous step, around the axis of symmetry, to create a solid body, which volume is $V_{\text {stock. }}$. 
Fig. 3 Process for defining the 3D CAD model of an open-die forged axisymmetric part. (C) 2020 Baker Hughes Company. All rights reserved

\subsubsection{Type and dimensions of raw material}

The raw material of a forging process, for axisymmetric components, consists of round billets or round custom ingots [36]. The former is used for medium-sized components, which volume is less than $200 \mathrm{dm}^{3}$; otherwise, custom ingots are used [39]. Dimensions of the raw material are computed according to the systems of equations presented in Table 1. Diameter and length of a billet are computed considering a slenderness
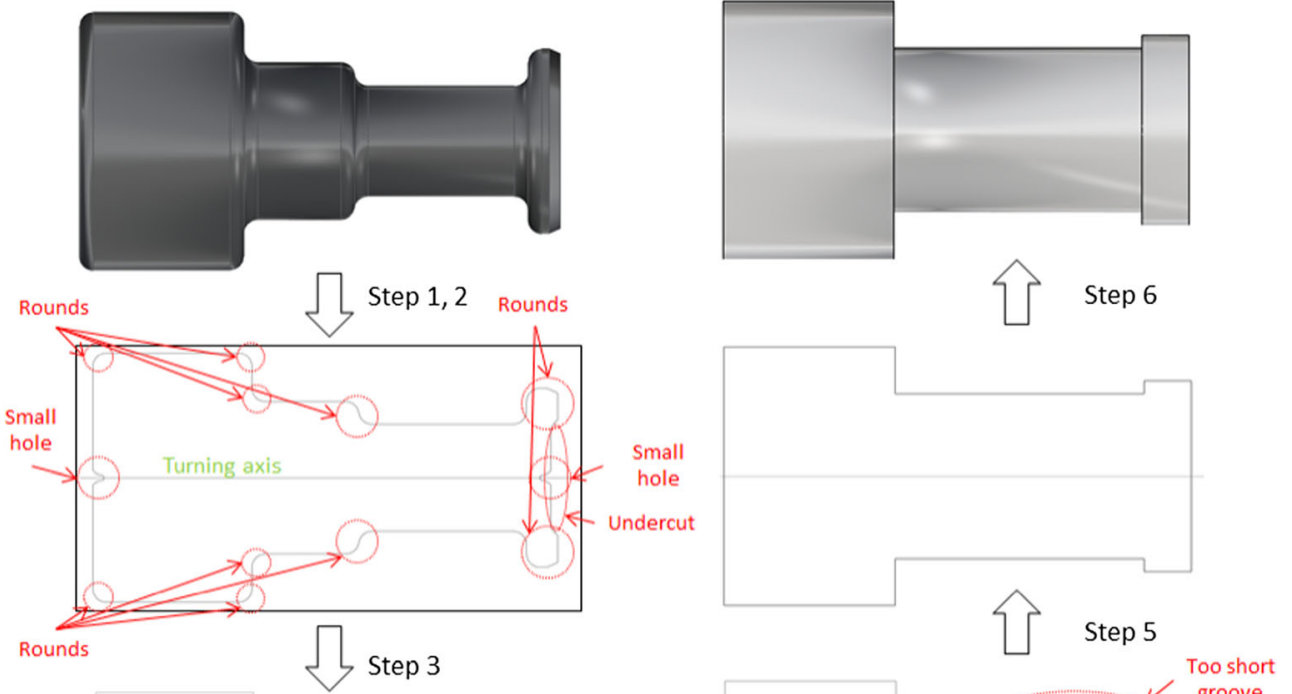

Step 4<smiles>C1CC2CCC1C2</smiles>

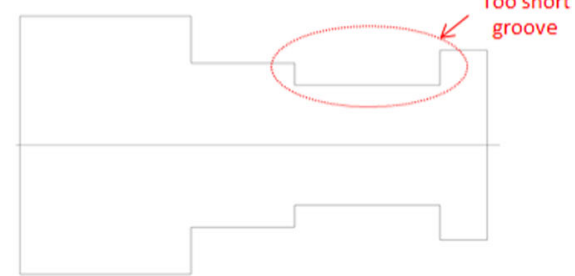

Table 1 Raw material types and dimensions. (C) 2020 Baker Hughes Company. All rights reserved

\begin{tabular}{|c|c|c|c|c|}
\hline \multicolumn{3}{|c|}{ Raw material type } & Validity rules & Calculation rules \\
\hline Billet & ț & $l_{\text {raw }}$ & $\begin{array}{l}V_{\text {stock }} \\
\leq 200 \mathrm{dm}^{3}\end{array}$ & $\left\{\begin{array}{c}V_{\text {stock }}=\left(\frac{\pi \cdot d_{\text {raw }}^{2}}{4} \cdot l_{\text {raw }}\right) \cdot\left(1+\frac{S_{\text {scale lost }}}{100}\right) \\
\frac{l_{\text {raw }}}{d_{\text {raw }}}=2(\text { min: } 1.5 ; \max : 3.0) \\
V_{\text {forged }}=V_{\text {stock }}\end{array}\right.$ \\
\hline $\begin{array}{c}\text { Custom } \\
\text { ingot }\end{array}$ & 咅 & $l_{\text {raw }}$ & $\begin{array}{l}V_{\text {stock }} \\
>200 \mathrm{dm}^{3}\end{array}$ & $\left\{\begin{array}{c}V_{\text {stock }}=\frac{\pi \cdot l_{\text {raw }} \cdot\left(D_{\text {raw }}^{2}+D_{\text {raw }} \cdot d_{\text {raw }}+d_{\text {raw }}^{2}\right)}{12} \cdot\left(1+\frac{S_{\text {scale lost }}}{100}\right) \\
\frac{D_{\text {raw }}}{d_{\text {raw }}}=1.15(\text { min: } 1.10 ; \text { max: } 1.20) \\
\frac{l_{\text {raw }}}{D_{\text {raw }}}=1.75(\text { min }: 1.5 ; \text { max: }: 2.0) \\
V_{\text {forged }}=\frac{V_{\text {stock }}}{0.9}\end{array}\right.$ \\
\hline
\end{tabular}

factor $\left(l_{\text {raw }} / d_{\text {raw }}\right)=2$ (required for avoiding billet axial flexion during initial cogging) and the raw material volume $\left(V_{\text {stock }}\right)$. It is worth noting that billets dimensions are standardised by regulations. Hence, the diameter previously computed should be rounded to the nearest value expected by billets handbook. If the updated slenderness factor is higher than 3.0 or lower than 1.5 , a custom billet should be adopted.

Ingots (truncated cone shape) are used for significant forged components, which volume is higher than $200 \mathrm{dm}^{3}$. 
The shape is determined by $D_{\text {raw }}, d_{\text {raw }}$ and $l_{\text {raw }}$, each one related according to equations available in Table 1. Ingots have two protuberances, one at each end, required for their rotation during forging, which volume is around $10 \%$ of the forged component $V_{\text {stock }}$ [40]. Since ingots are custom-made, it is not necessary to round dimensions previously computed.

The hot forging process generates material scale (loss of material when heated over the scaling temperature, around $1200-1300{ }^{\circ} \mathrm{C}$ for steel), which quantity depends by its resistance to oxidation. The billet and ingots sizes should consider this loss of material through the scale factor $S_{\text {scale lost }}$ This parameter depends on the material (e.g. is minimum for stainless steel) and shape (i.e. the bigger the volume/surface ratio, the lower the scale factor). Here are reported some typical values for a round billet (length/diameter $=2.0$ ): $1.0 \%$ for nickel alloy, $5.0 \%$ for carbon steel and $0.2 \%$ for aluminium.

\subsubsection{Raw material cost assessment}

Material cost (Eq. 2) is the most impacting cost item [28]. Material cost $\left(C_{\text {material }}\right)$ considers the cost of raw material and the revenues from the scraps due to the recyclability of the metals used in the forging process.

$C_{\text {material }}=C u_{\text {material }} \cdot \rho \cdot V_{\text {forged }}-C u_{\text {scrap }} \cdot \rho \cdot V_{\text {scrap }}$

$C u_{\text {material }}$ is the unitary price of virgin material, $V_{\text {forged }}$ is the volume of material required for the forging process, even considering extra material like protuberances, $C u_{\text {scrap }}$ is the unitary price of forging scraps, $V_{\text {scrap }}$ is the volume of scrapped material and $\rho$ is the material density. Scrap volume $\left(V_{\text {scrap }}\right)$ refers to the volume that can be recovered and which can be resold with revenues. This is null for billets, whereas it is the volume of protuberances for ingots.

\subsection{Cutting cost}

Cutting cost (Eq. 3) is the cost of a preliminary operation, which is required only for billets (for ingots, this operation is not necessary). The method of cutting off bars is determined by the edge condition required for subsequent operations and by the base area of the billet. Bar sawing usually produces a uniform cut edge with few or no microstructure deformations close to the cutting section. Separation of billets by shearing is a process without material loss and with considerably higher output rate than sawing, abrasive cutting or flame cutting.

Cutting $\operatorname{cost}\left(C_{\text {cutting }}\right)$ is the multiplication between the processing time $(t)$ with the hourly machine rate $\left(M . C_{u}\right)$.

$$
C_{\text {cutting }}=t \cdot M \cdot C_{u}=\left(t_{\text {cutting }}+\frac{t_{\text {setup }}}{P_{b}}+t_{\text {load } / \text { unload }}\right) \cdot M \cdot C_{u}
$$

Geometric cost drivers (Table 2) for shearing and sawing are the same ones, and they are related to the billet to be cut (material $M$, billet diameter $d_{\text {raw }}$ and weight $W$ ) and to be production batch $\left(P_{b}\right)$. Process cost drivers, instead, differentiate a bit to each other. For sawing, the cutting rate is required ( $R_{\text {cutting }}$ depends by the material and machine [12]), whereas, for shearing, it is necessary the shearing force $\left(F_{\text {shearing }}\right)$, shearing temperature $\left(T_{s}\right)$, material shear stress $\left(Y_{\text {shear }}\right)$ and the machine forging rate (M.n $\left.n_{\text {stroke }}\right)$.

Shearing is commonly used for billets whose diameter is lower than $300 \mathrm{~mm}$, because, the higher the billet diameter, the higher the press power. Sawing has no limits of validity. Shearing is convenient for medium-high production volumes (more than 100 pieces, unusual for open-die forging) because this process requires higher set-up time. Such rules are described by process validity and priority rules presented in Table 2 . In case shearing and sawing are both valid solutions (i.e. billet diameter $<300 \mathrm{~mm}$ ), the best one is selected according to the "priority" parameter (the higher the priority, the best the process).

The shearing process is generally realised using different types of machine (M.T), such as hammers or hydraulic presses. The following parameters characterise each cost centre: power (M.P: the shearing force for presses), energy (M.E: the deforming energy for hammers), stroke (M.S), width (M.W: the maximum billet dimension), head width $\left(M h_{\text {width }}\right.$ : the dimension of the forging tool), forging rate (M. $n_{\text {stroke }}$ : the

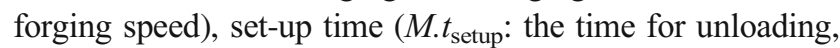
loading the hammer) and cost rate $\left(M . C_{u}\right.$ : the unitary cost that includes energy, labour, depreciation and consumable). Sawing is realised using different types of machine (M.T), such as hinge or double column types. The main parameters are width (M.W: the maximum billet dimension), set-up time (M.t.$_{\text {setup }}$ : the time for cleaning and adjusting the machine), speed (M.sp: the maximum blade speed) and cost rate $\left(M . C_{u}\right.$ : the unitary cost that includes energy, labour, depreciation and consumable).

A shearing press is selected according to the force required for shearing the billet $\left(F_{\text {shearing }}=1.15 \cdot Y_{\text {shear }} \cdot \pi \cdot d_{\text {raw }}{ }^{2} / 4\right)[1,12]$ and the billet diameter $\left(d_{\text {raw }}\right)$. The constant of 1.15 is a safety factor of $15 \%$ [7]. The equivalent material shear stress $\left(Y_{\text {shear }}\right)$ is a function of shearing temperature $\left(T_{s}\right)$. In case of hot cutting (around $1.300{ }^{\circ} \mathrm{C}$ for steel), equivalent shear stress is around $1 / \sqrt{ } 3$ of the flow stress of material (i.e. the instantaneous value of stress required to continue plastically deforming the material) at forging temperature, while in case of cold cutting (environmental temperature), equivalent shear stress is about $1 / \sqrt{3}$ of the ultimate tensile strength of the material (i.e. the force required to break a material). The value of $1 / \sqrt{ } 3$ derives from von Mises yield criterion [1, 12]. A sawing machine is selected according to the billet dimension. The band saw capacity (M.W) must be greater than the billet diameter $\left(d_{\text {raw }}\right)$. In case of multiple valid presses, hammers or band saws, the most convenient is selected. 
Table 2 Cost model for billet cutting. (C) 2020 Baker Hughes Company. All rights reserved

\begin{tabular}{|c|c|c|}
\hline & Shearing & Sawing \\
\hline \multirow[t]{4}{*}{ Geometric cost drivers } & Material $(M)$ & Material $(M)$ \\
\hline & Billet diameter $\left(d_{\text {raw }}\right)\left[\mathrm{mm}^{2}\right]$ & Billet diameter $\left(d_{\text {raw }}\right)\left[\mathrm{mm}^{2}\right]$ \\
\hline & Billet weight $(W)[\mathrm{kg}]$ & Billet weight $(W)[\mathrm{kg}]$ \\
\hline & Production batch $\left(P_{b}\right)[-]$ & Production batch $\left(P_{b}\right)[-]$ \\
\hline \multirow[t]{8}{*}{ Process cost drivers } & Shearing force $\left(F_{\text {shearing }}\right)[\mathrm{N}]$ & Cutting rate $\left(R_{\text {cutting }}\right)\left[\mathrm{mm}^{2} / \mathrm{min}\right]$ \\
\hline & Material shear stress $\left(Y_{\text {shear }}\right)[\mathrm{MPa}]$ & Cutting time $\left(t_{\text {cutting }}\right)[\mathrm{min}]$ \\
\hline & Shearing temperature $\left(T_{s}\right)\left[{ }^{\circ} \mathrm{C}\right]$ & Load and unload time $\left(t_{\text {load} / \text { unload }}\right)[\mathrm{min}]$ \\
\hline & Machine forging rate $\left(M \cdot n_{\text {stroke }}\right)\left[\mathrm{min}^{-1}\right]$ & Setup time $\left(t_{\text {setup }}\right)[\mathrm{min}]$ \\
\hline & Cutting time $\left(t_{\text {cutting }}\right)[\mathrm{min}]$ & Process time $(t)[\mathrm{min}]$ \\
\hline & Load and unload time $\left(t_{\text {load/unload }}\right)[\mathrm{min}]$ & \\
\hline & Setup time $\left(t_{\text {setup }}\right)[\mathrm{min}]$ & \\
\hline & Process time $(t)[\mathrm{min}]$ & \\
\hline Process validity rules & $A_{\text {billet }}<70.000 \mathrm{~mm}^{2}$ & - \\
\hline Process priority rules & Priority $=\operatorname{IIF}\left(\mathrm{P}_{\mathrm{b}}>100 ; 20 ; 0\right)$ & Priority $=10$ \\
\hline \multirow[t]{7}{*}{ Process calculation rules } & $Y_{\text {shear }}=f(M)$ & $R_{\text {cutting }}=f(M, M . S p)$ \\
\hline & $F_{\text {shearing }}=1.15 \cdot \frac{\pi \cdot d_{\text {raw }}^{2}}{4} \cdot Y_{\text {shear }}$ & $t_{\text {cutting }}=\frac{\frac{\pi \cdot d_{\text {raw }}^{2}}{4}}{R_{\text {cutting }}}$ \\
\hline & $M . n_{\text {stroke }}=f(M . T)$ & $t_{\text {load } / \text { unload }}=f(W)$ \\
\hline & $t_{\text {cutting }}=\frac{1}{M \cdot n_{\text {stroke }}}$ & $t_{\text {setup }}=M \cdot t_{\text {setup }}$ \\
\hline & $t_{\text {load/unload }}=f(W)$ & $t=t_{\text {cutting }}+t_{\text {load } / \text { unload }}+\frac{t_{\text {setup }}}{P_{b}}$ \\
\hline & $t_{\text {setup }}=M \cdot t_{\text {setup }}$ & \\
\hline & $t=t_{\text {cutting }}+t_{\text {load } / \text { unload }}+\frac{t_{\text {setup }}}{\text { p }} P_{b}$ & \\
\hline \multirow[t]{9}{*}{ Cost centre parameters } & Type (M.T) [-] & Type (M.T) [-] \\
\hline & Power (M.P) $[\mathrm{N}]$ & Width (M.W) [mm] \\
\hline & Energy (M.E) [kJ] & Speed (M.Sp) [m/min] \\
\hline & Stroke (M.S) [mm] & Setup time (M.tsetup $)[\mathrm{min}]$ \\
\hline & Width (M.W) [mm] & Cost rate $\left(\mathrm{M}_{\mathrm{C}} \mathrm{C}_{\mathrm{u}}\right)[€ /$ hour $]$ \\
\hline & Head width $\left(\mathrm{M} . \mathrm{H}_{\text {width }}\right)[\mathrm{mm}]$ & \\
\hline & Forging rate $\left(\mathrm{M} \cdot \mathrm{n}_{\text {stroke }}\right)$ & \\
\hline & Setup time $\left(M \cdot t_{\text {setup }}\right)[\mathrm{min}]$ & \\
\hline & Cost rate $\left(\mathrm{M} . \mathrm{C}_{\mathrm{u}}\right)[€ /$ hour $]$ & \\
\hline Cost centres validity rules & $\begin{array}{l}\text { M.P }>F_{\text {shearing }} \\
\text { M.W }>d_{\text {raw }}\end{array}$ & M.W $>d_{\text {raw }}$ \\
\hline Cost centres priority rules & $\operatorname{MIN}\left({\left.\mathrm{M} . \mathrm{C}_{\mathrm{u}}\right)}\right)$ & $\operatorname{MIN}\left(\mathrm{M}_{\mathrm{C}} \mathrm{C}_{\mathrm{u}}\right)$ \\
\hline
\end{tabular}

\subsection{Heating cost}

Before being forged, a billet or an ingot must be heated up to a fixed temperature (forging max temperature $\left(T_{\text {f.max }}\right)$ ) which is over the material recrystallisation temperature. This process enables a part to be forged with minimum pressure and to produce finished parts that have reduced residual stress, thus making it easy for machining or heat treatment. Generally, heating takes place in gas or electric convection furnaces. For any forging material, the heating time is directly connected with the forging temperature and must be kept until the centre of the forging stock reach the forging temperature. A heating time longer than necessary results in excessive decarburisation, scale and grain growth.
Heating cost $\left(C_{\text {heating }}\right)$ is the multiplication between the processing time $(t)$ with the hourly furnace rate $\left(M . C_{u}\right)$.

$C_{\text {heating }}=t \cdot M \cdot C_{u}=\left(t_{\text {heating }}+N_{\text {re-heat }} \cdot t_{\text {re-heating }}+t_{\text {setup }}+t_{\text {load } / \text { unload }}\right) \cdot M \cdot C_{u}$

Furnace unitary cost rate $\left(M . C_{u}\right)$ includes energy, labour, depreciation and consumable.

When the forging time $\left(t_{\text {forging }}\right.$, the time required to achieve all forging process: pre-smoothing, smoothing, upsetting, max-shoulder cogging, necking and other shoulders cogging) is too long, the temperature of the piece could decrease under the forging temperature limit (forging min temperature 
$\left(T_{\text {f.min }}\right)$ ), requiring the reheating of the piece. Reheating is typical in large axial parts, as shafts used in gas or steam turbines. Forging temperature decreases under the temperature limit for forging in a fixed time ( $\left.t_{\text {cooling }}\right)$, which is a function of material $(M)$ and part weight $(W)$.

Minimum and maximum forging temperatures depend on material type, while heating time ( $t_{\text {heating }}$ ) is a function of material and piece dimensions. For example, for a steel stock measuring up to $75 \mathrm{~mm}$ in diameter, the heating time per inch of section thickness should be no more than 5 min for lowcarbon and medium-carbon steels or no more than 6 min for low-alloy steels [39]. Heating time speed increases with the billet diameter parameter [39]. For small pieces, the heating cost is relatively small because single heating is enough, but for bigger ones, several reheats between operations may be required. Furnace set-up time $\left(t_{\text {setup }}\right)$ is generally negligible because it is always running. When required, set-up consists only in the rapid cleaning of the furnace. Reheating time $\left(t_{\text {re- }}\right.$ heating) is a function of material, piece dimensions and forging temperature. The total quantity of necessary reheats depends on the ratio between forging time ( $\left.t_{\text {forging }}\right)$ and cooling time $\left(t_{\text {cooling }}\right)$.

Geometric cost drivers (Table 3) are related to the part to be heated (billet diameter $\left(d_{\text {raw }}\right)$, ingot small diameter $\left(d_{\text {raw }}\right)$, ingot large diameter $\left(D_{\text {raw }}\right)$, billet/ingot length $\left(l_{\text {raw }}\right)$, smoothing diameter $\left(d_{\text {smoothing }}\right)$, smoothing length $\left(l_{\text {smoothing }}\right)$, upsetting diameter $\left(d_{\text {upsetting }}\right)$, upsetting length $\left(l_{\text {upsetting }}\right)$, max-shoulder diameter $\left(d_{\text {max-shoulder }}\right)$, max-shoulder length $\left(l_{\text {max-shoulder }}\right)$, necking diameter $\left(d_{\text {necking }}\right)$, necking length $\left(l_{\text {necking }}\right)$, final length $\left(l_{\text {part }}\right)$ and billet/ingot weight $(W)$. The furnace dimensions (length (M.L), width (M.W), height (M.H)) must be higher than the bounding box of the forged part to be heated.

\subsection{Forging cost}

The open-die forging process consists of several phases: (i) pre-smoothing, (ii) smoothing, (iii) upsetting, (iv) maxshoulder cogging, (v) necking and (vi) other shoulders cogging. The first two (pre-smoothing and smoothing) are preliminary phases to ensure the part cylindricity before upsetting, so they are needed only when forging begins from ingots since billets are already cylindrical. Axisymmetric components could have a fixed number of shoulders, and this affects the duration of the last 2 phases (necking and other shoulders cogging), eliminating them in case of shoulders absence. Forging $\operatorname{cost}\left(C_{\text {forging }}\right)$ can be calculated as follows.

$$
\begin{aligned}
C_{\text {forging }}= & C_{\text {pre-smoothing }}+C_{\text {smoothing }}+C_{\text {upsetting }} \\
& +C_{\text {max-shoulder cogging }}+C_{\text {necking }} \\
& +C_{\text {shoulders cogging }}
\end{aligned}
$$

All the forging phases are achieved using a unique machine, and its choice is based on the dimensions of the forged part and the loads (energy) produced during the upsetting phase. In fact, in this phase, the part reaches the maximum width and are generated the highest loads.

Forging machine size limits must be compared with raw material and forged piece dimensions. Two dimensions must be considered: (i) maximum machine width $(M . W)$ and (ii) maximum machine stroke (M.S). Machine width must be greater than the component diameter after upsetting operation $\left(d_{\text {upsetting }}\right)$, in which the part achieves the maximum diameter. Instead, machine stroke cannot be lower than the highest dimension between the forged diameter after upsetting and the forged height prior upsetting $\left(t_{\text {smooting }}\right.$ or $t_{\text {raw }}$ depending on the raw material type).

Once filtered, the first number of available machines that can hold the forged part, energy or load required for forging must be calculated for selecting the right machine size. Opendie forging is realised employing hydraulic presses (loadrestricted machines) and hammers (energy-restricted machines). Press forging is generally more efficient than hammer one. During hammer forging, the hammer absorbs a lot of the energy that could otherwise be focused on the workpiece. Press forging allows excellent efficiency and more control over the forging of the piece.

As mentioned above, the upsetting determines the highest deformations, and therefore, the highest demand for force and energy. So, if a hydraulic press is used, it is necessary to compute the force needed to upset the piece. In this case, the operation must be carried out in one stroke, and the machine must have a tonnage higher than the force for upsetting $\left(F_{\text {upsetting }}\right.$ ). If a hammer is used, the energy to deform the piece must be calculated. The piece upsetting can be made with multiple strokes. The number of required strokes $\left(N_{\text {upsetting- }}\right.$ stroke) multiplied by the machine energy must be greater than the deformation energy $\left(E_{\text {upsetting }}\right)$. Force $\left(F_{\text {upsetting }}\right)$ and energy for upsetting $\left(E_{\text {upsetting }}\right)$ are a function of strain $(\varepsilon)$, strain rate strength $\left(K^{\prime}\right)$ and strain rate sensitivity exponent $(m)$, which depends on the material, part dimensions and machine characteristics [4]. Also, the strain rate $(\xi)$ has an essential role in load and energy, and it represents the ratio between machine ram speed (M.V) and forging length after upsetting ( $l$ upsetting). Thus, the energy or the force for upsetting increase with machine speed. Generally, larger machines have low ram speed. Maximum force for upsetting occurs when the part achieves the minimum length at forging process; in fact, in this condition, the forged piece achieves his maximum area ( $A_{\text {upsetting }}$ ) and his maximum strain rate. The magnitude of force and energy for piece upsetting is influenced by the lubricant used at the die-workpiece interface for reducing friction. Friction multiplying factor $\left(Q_{a}\right)$ affects force and energy required and it is a function of friction coefficient $(\mu)$ and geometry ratio $\left(d_{\text {upsetting }} / l_{\text {upsetting }}\right)$ of the part at the end of 
Table 3 Cost model for heating. (c) 2020 Baker Hughes Company. All rights reserved

Heating

Geometric cost drivers

Material $(M)$

Billet diameter $\left(d_{\text {raw }}\right)\left[\mathrm{mm}^{2}\right]$

Ingot small diameter $\left(d_{\text {raw }}\right)\left[\mathrm{mm}^{2}\right]$

Ingot large diameter $\left(D_{\text {raw }}\right)\left[\mathrm{mm}^{2}\right]$

Billet/ingot length $\left(l_{\text {raw }}\right)\left[\mathrm{mm}^{2}\right]$

Diameter after smoothing $\left(d_{\text {smoothing }}\right)[\mathrm{mm}]$

Length after smoothing $\left(l_{\text {smoothing }}\right)$

Diameter after upsetting $\left(d_{\text {upsetting }}\right)[\mathrm{mm}]$

Length after upsetting $\left(l_{\text {upsetting }}\right)[\mathrm{mm}]$

Diameter after max-shoulder $\left(d_{\text {max-shoulder }}\right)$ [mm]

Length after max-shoulder $\left(l_{\text {max }}\right.$-shoulder $)[\mathrm{mm}]$

Diameter after necking $\left(d_{\text {necking }}\right)[\mathrm{mm}]$

Length after necking $\left(l_{\text {necking }}\right)[\mathrm{mm}]$

Diameter after max-shoulder $\left(d_{\text {max-shoulder }}\right)[\mathrm{mm}]$

Length of part after forging operations $\left(l_{\text {part }}\right)[\mathrm{mm}]$

Process cost drivers

Billet/ingot weight $(W)[\mathrm{kg}]$

Max forging temperature $\left(T_{f \cdot \max }\right)\left[{ }^{\circ} \mathrm{C}\right]$

Min forging temperature $\left(T_{f \cdot \text { min }}\right)\left[{ }^{\circ} \mathrm{C}\right]$

Cooling time $\left(t_{\text {cooling }}\right)$ [min]

Heating time ( $\left.t_{\text {heating }}\right)$ [min]

Re-heating time $\left(t_{\text {re-heating }}\right)$ [min]

Re-heat number $\left(N_{\text {re-heat }}\right)[-]$

Forging time $\left(t_{\text {forging }}\right)$ [min]

Load and unload time ( $\left.t_{\text {load/unload }}\right)$ [min]

Setup time $\left(t_{\text {setup }}\right)[\mathrm{min}]$

Process validity rules

Process time $(t)$ [min]

Process priority rules

Process calculation rules

$T_{f . \max }=f(M)$

$T_{f . \min }=f(M)$

$t_{\text {heating }}=f\left(M, T_{f . \max }, W\right)$

$t_{\text {cooling }}=f\left(M, T_{f . \min }, W\right)$

$t_{\text {re }- \text { heating }}=f\left(M, T_{f . \min }, T_{f . \max }, W\right)$

$N_{\text {re-heat }}=\operatorname{IFS}\left(t_{\text {forging }}>t_{\text {cooling }} ; \operatorname{CEILING}\left(\frac{t_{\text {forging }}}{t_{\text {cooling }}}\right) ; 0\right)$

$t_{\text {load/unload }}=f(W)$

$t_{\text {setup }}=M . t_{\text {setup }}$

$t=t_{\text {heating }}+N_{\text {re }- \text { heat }} \cdot t_{\text {re }- \text { heating }}+t_{\text {setup }}+t_{\text {load } / \text { unload }}$

Cost centre parameters

Length (M.L) [mm]

Width (M.W) [mm]

Height (M.H) $[\mathrm{mm}]$

Setup time (M.t setup $)$ [min]

Cost rate (M.C. $\mathrm{C}_{\mathrm{u}}$ [ $[€ /$ hour $]$

Cost centres validity rules

M.L > MAX $\left[1_{\text {raw }} ; 1_{\text {smoothing }} ; 1_{\text {upsetting }} ; 1_{\text {max-shoulder }} ; 1_{\text {necking }} ; 1_{\text {part }}\right]$

IFS (=raw material type $=$ billet; M.W > MAX $\left[\mathrm{d}_{\text {raw }} ; \mathrm{d}_{\text {upsetting }} ; \mathrm{d}_{\text {smoothing }} ; \mathrm{d}_{\text {max-shoulder }}\right.$;

$\mathrm{d}_{\text {necking }} ;$ raw material type $=$ ingot; $\left.\mathrm{M} . \mathrm{W}>\operatorname{MAX}\left[\mathrm{D}_{\text {raw }} ; \mathrm{d}_{\text {upsetting }} ; \mathrm{d}_{\text {smoothing }} ; \mathrm{d}_{\text {max-shoulder }} ; \mathrm{d}_{\text {necking }}\right]\right)$

IFS (Raw material type = billet; M.H $>$ MAX $\left[\mathrm{d}_{\text {raw }} ; \mathrm{d}_{\text {upsetting }} ; \mathrm{d}_{\text {smoothing }} ; \mathrm{d}_{\text {max-shoulder }}\right.$;

$\mathrm{d}_{\text {necking}} ;$ Raw material type $=$ ingot; $\left.M . H>\operatorname{MAX}\left[\mathrm{D}_{\text {raw }} ; \mathrm{d}_{\text {upsetting }} ; \mathrm{d}_{\text {smoothing }} ; \mathrm{d}_{\text {max-shoulder }} ; \mathrm{d}_{\text {necking }}\right]\right)$

Cost centres priority rules MIN (M.C ${ }_{\mathrm{u}}$ )

upsetting operation [4]. In the case of axisymmetric parts with high diameter-height ratio, such as discs, geometry ratio comes from the technical draft of the part. On the other hand, when the diameter-height ratio is small, such as shafts, forge masters recommended value of 1.5 .

Machine size affects the hourly cost and the number of parts formed per minute. Larger machines generally have higher costs and a lower stroke rate, while light machines are less expensive and faster. The hourly machine rate increases whit machine dimensions not only due to higher energy consumption but also due to the more significant number of operators required, which is directly proportional to the machine size. The following parameters characterise each cost centre: power (M.P: the force for 
presses), energy (M.E: deforming energy for hammers), stroke (M.S), width $(M . W)$, forging rate $\left(M . n_{\text {stroke }}\right.$ : forging speed), set-up time (M.t $t_{\text {setup }}$ : time for unloading, loading the hammer) and cost rate $\left(M . C_{u}\right.$ : the unitary cost that includes energy, labour, depreciation and consumable). In the case of multiple valid presses or hammers, the most convenient is selected.

\subsubsection{Pre-smoothing cost}

Pre smoothing is a preliminary operation to be performed only in case of ingot forging. It consists of hot removal of the small protuberance of the ingot, which contains the impurities generated during ingot casting. The volume of the protuberance is generally a low percentage of the ingot volume (2\%) [40]. This operation can be carried out only with a hydraulic press, which allows the shear of material. Pre smoothing cost $\left(C_{\text {pre-smoothing }}\right)$ can be calculated as follows:

$C_{\text {pre-smoothing }}=t \cdot M \cdot C_{u}=\left(t_{\text {pre-smoothing }}+t_{\text {accessory }}+t_{\text {load } / \text { unload }}\right) \cdot M \cdot C_{u}$

Pre-smoothing time is the time required to shear the small protuberance, and it is the reverse of machine stroke rate (M. $\left.n_{\text {stroke }}\right)$.

The accessory time ( $\left.t_{\text {accessory }}\right)$ consists of preliminary operations, as die mounting and cleaning, for forging process. The production batch $\left(P_{b}\right)$ is not considered for accessory time amortisation cause these preliminary operations are carried for every forged piece. The accessory time is a fixed time function of part weight $(W)$.

Geometric cost drivers (Table 5) for pre-smoothing are related to the ingot to be formed (material $M$, ingot small diameter $d_{\text {raw }}$, ingot large diameter $D_{\text {raw }}$, ingot length $l_{\text {raw }}$ and weight $W$ ) and the volume of the part after presmoothing phase (pre-smoothing volume ( $\left.V_{\text {pre-smoothing }}\right)$ (Table 4)). The principal process cost driver required is the forging machine rate (M.n $\left.n_{\text {stroke }}\right)$, which depends on machine size.

\subsubsection{Smoothing cost}

Smoothing consists of ingot radial deformation to turn it into a cylindrical part by using a hydraulic press. All the radial deformation operations (smoothing, max shoulder cogging, other shoulders cogging) are carried out according to the same pattern, reforming consecutively on the square, hexagon, octagon and circle (supposed a polygon whit 32 sides) $[35,30]$. The piece goes forward along the work area of the forging machine and undergoes different compressions.
Smoothing cost $\left(C_{\text {smoothing }}\right)$ can be calculated as follows.

$C_{\text {smoothing }}=t \cdot M \cdot C_{u}=\left(t_{\text {smoothing }}+t_{\text {accessory }}+t_{\text {load } / \text { unload }}\right) \cdot M . C_{u}$

Accessory time ( $t_{\text {accessory }}$ ) consists only in the rapid cleaning of the die, and it is realised for every part. Smoothing time ( $\left.t_{\text {smoothing }}\right)$ is the time required to obtain the cylindrical shape. This time is calculated as the ratio between the number of strokes required for smoothing operation $\left(N_{\text {smoothing-stroke }}\right)$ and machine stroke rate $\left(M . n_{\text {stroke }}\right)$. The number of strokes required for smoothing operation ( $\left.N_{\text {smoothing-stroke }}\right)$ is a function of part length at the end of the operation $\left(l_{\text {smoothing }}\right)$ and die length $\left(l_{\text {die }}\right)$. In radial forging, dies have a rectangular shape, whose width $\left(w_{\text {die }}\right)$ is equal to the width of the machine, while the die length $\left(l_{\text {die }}\right)$ affects the number of strokes and therefore the time required for forging. During radial forging, only a percentage of the die width is used $\left(f_{\mathrm{die}}\right)$, and this percentage is placed equal to $60 \%$ (in industrial practice is generally $40-75 \%$ of the length of the die).

Smoothing length $\left(l_{\text {smoothing }}\right)$ depends on smoothing volume ( $\left.V_{\text {smoothing }}\right)$ (Table 4) and component diameter at the end of the smoothing process $\left(d_{\text {smoothing }}\right)$. The diameter achieved after smoothing $\left(d_{\text {smoothing }}\right)$ is supposed $90 \%$ of ingot smallest diameter $\left(d_{\text {raw }}\right)[40]$.

Other geometric cost drivers (Table 5) for smoothing are the same as for pre-smoothing operation. These cost drivers are related to the ingot to be formed (material $M$, ingot small diameter $d_{\text {raw }}$, ingot large diameter $D_{\text {raw }}$, ingot length $l_{\text {raw }}$ and weight $W$ ) and the volume of the part after the smoothing phase (smoothing volume $\left(V_{\text {smoothing }}\right)$ ).

\subsubsection{Upsetting cost}

Upset forging is a manufacturing process that decreases the length of the workpiece to increase its diameter [34]. The upsetting requires the part repositioning in the forging machine to perform compressive strength along the central axis of the cylinder obtained from the previous operations with radial strength.

Upsetting $\operatorname{cost}\left(C_{\text {upsetting }}\right)$ can be calculated as follows.

$C_{\text {upsetting }}=t \cdot M \cdot C_{u}=\left(t_{\text {upsetting }}+t_{\text {accessory }}+\mathrm{t}_{\text {load } / \text { unload }}+t_{\text {setup }}\right) \cdot M . C_{u}$

Upsetting time ( $\left.t_{\text {upsetting }}\right)$ is calculated as the ratio between the number of strokes required for upsetting operation ( $\left.N_{\text {upsetting-stroke }}\right)$ and machine stroke rate $\left(M . n_{\text {stroke }}\right)$. The number of strokes required depends on the machine type, as previously described in Section 2.4.1. The 
Table 4 Raw material type and dimensions for forging operation. (C) 2020 Baker Hughes Company. All rights reserved

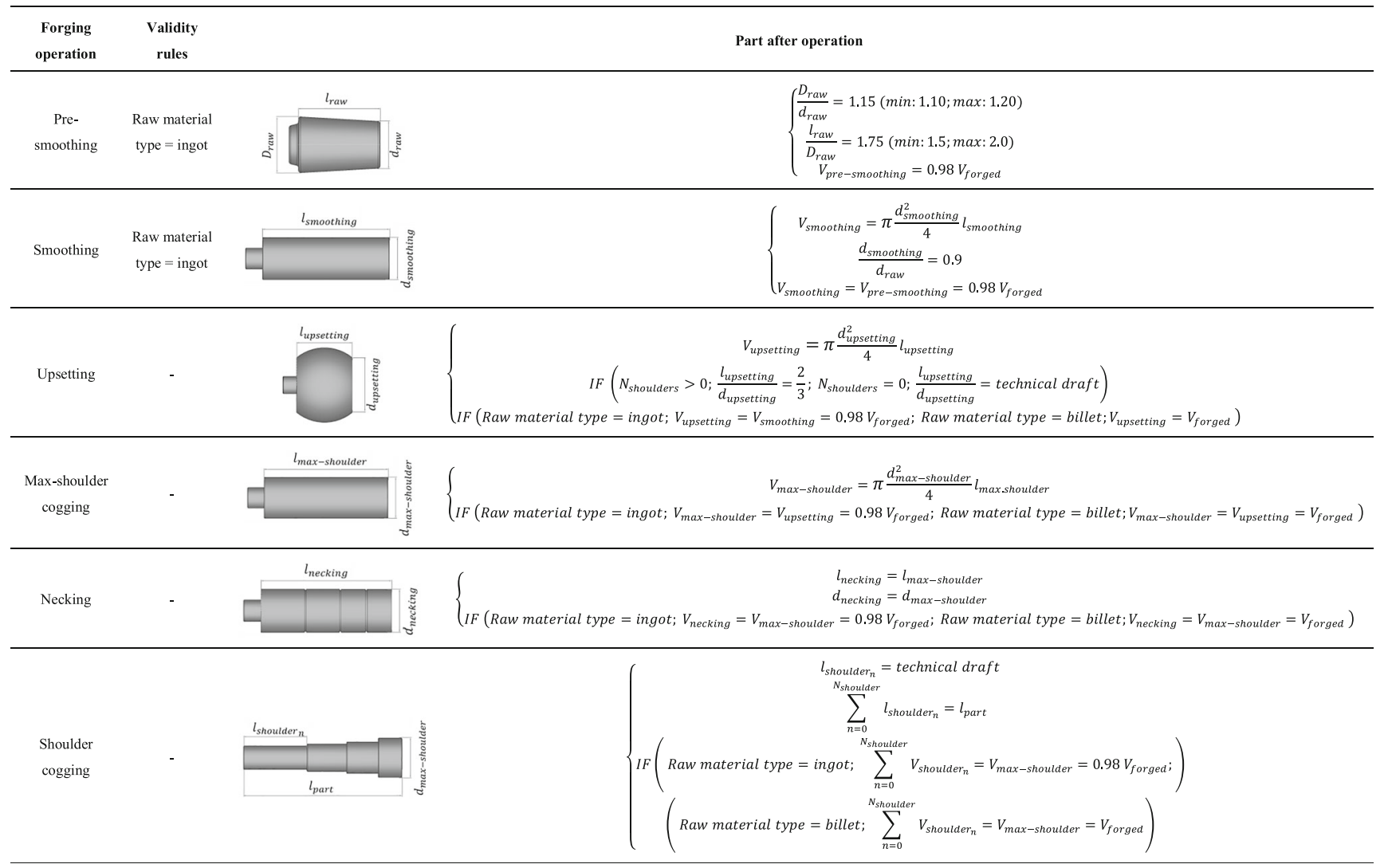

accessory time $\left(t_{\text {accessory }}\right)$ is the time required to change the die and this changing is carried out for each piece. In this operation, a circular shape die is used, instead of a rectangular die used in other forging operations. Set-up time is the time required to prepare the hammer or press for forging operations (gathering the tools for forging, press speed and force setting, forging machine test, etc.). It is worth noting that the set-up time is present only in this upsetting phase, since all the forging phases are achieved using a unique machine. In the case of axisymmetric parts whit high diameter-height ratio (i.e. discs), upsetting is considered the last operation in the forging process. Principals geometric cost drivers of upsetting phase are widely discussed in Section 2.4.1. The other geometric cost drivers (Table 5) for upsetting are the same considered in the previous operations. Geometrical cost drivers are related to the ingot or billet to be formed (material $M$, billet diameter $d_{\text {raw }}$, ingot small diameter $d_{\text {raw }}$, ingot large diameter $D_{\text {raw }}$, ingot/ billet length $l_{\text {raw }}$ and weight $W$ ), and the volume of the part after upsetting phase (upsetting volume ( $\left.V_{\text {upsetting }}\right)$ (Table 4). Process cost drivers for upsetting are related to the material ( $\max$ forging temperature $\left(T_{f \cdot \max }\right)$, the material strain rate strength $\left(K^{\prime}\right)$, the material strain rate sensitivity exponent $(m)$ ), and the part dimensions (strain rate $(\xi)$, strain $(\varepsilon)$, friction multiplying factor $\left.\left(Q_{a}\right)[4]\right)$ as reported in Table 5.

\subsubsection{Max-shoulder cogging cost}

Max-shoulder cogging consists of a radial deformation to turn the upset forged part into a cylindrical part using a hydraulic press. This operation allows bringing the upset part at the maximum shoulder diameter considering the final geometry of the forged part $\left(d_{\text {max-shoulder cogging }}\right)$.

$$
\begin{aligned}
& C_{\text {max-shoulder cogging }}=t \cdot M \cdot C_{u} \\
& \quad=\left(t_{\text {max }- \text { shoulder }}+t_{\text {accessory }}+t_{\text {load } / \text { unload }}\right) \cdot M \cdot C_{u}
\end{aligned}
$$

Max-shoulder cogging time ( $t_{\text {max-shoulder cogging }}$ ) is calculated in the same manner as the smoothing time (ratio between the number of strokes required for maxshoulder operation ( $\left.N_{\text {max-shoulder-stroke }}\right)$ and machine stroke rate $\left.\left(M . n_{\text {stroke }}\right)\right)$. 


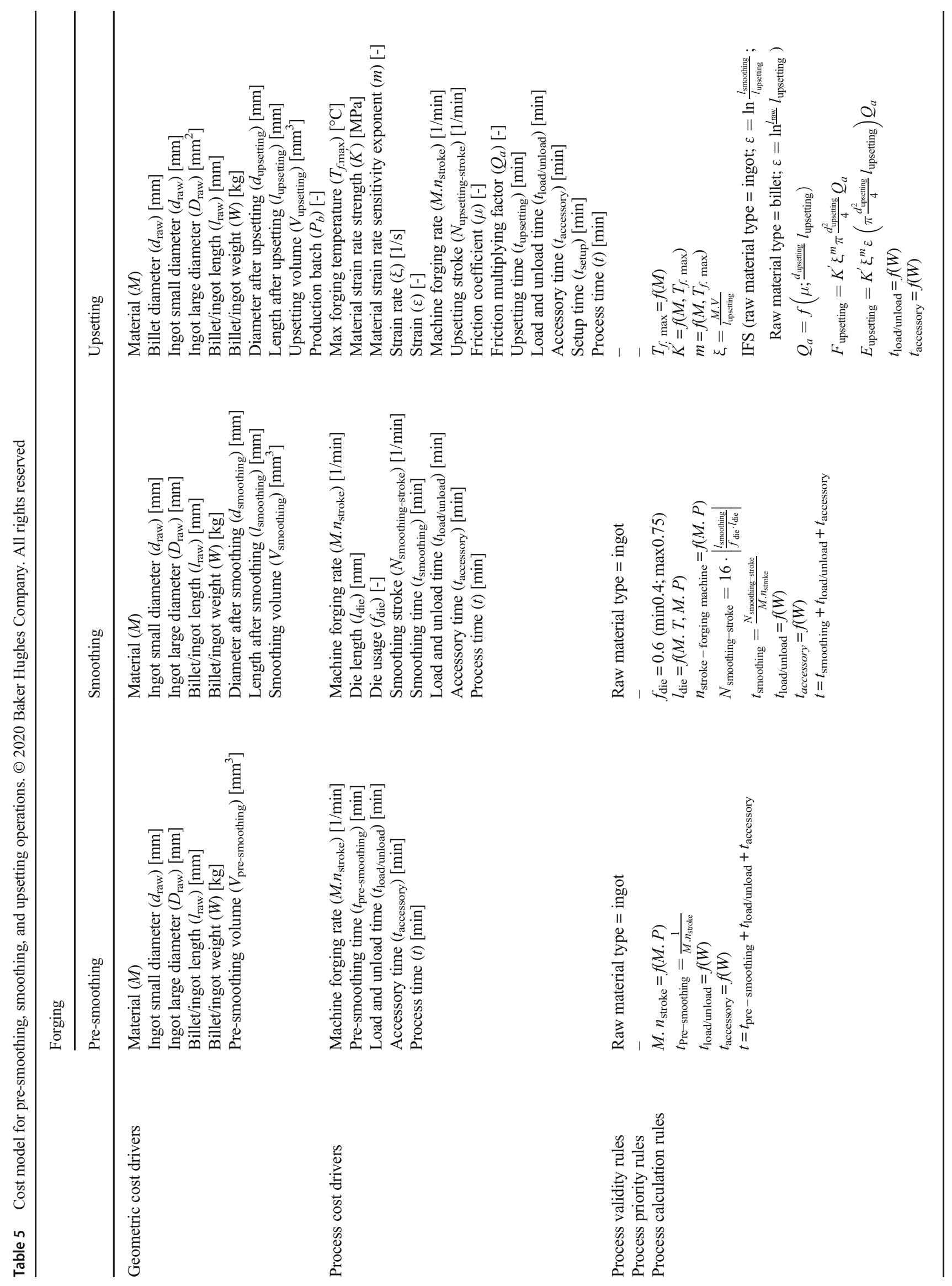




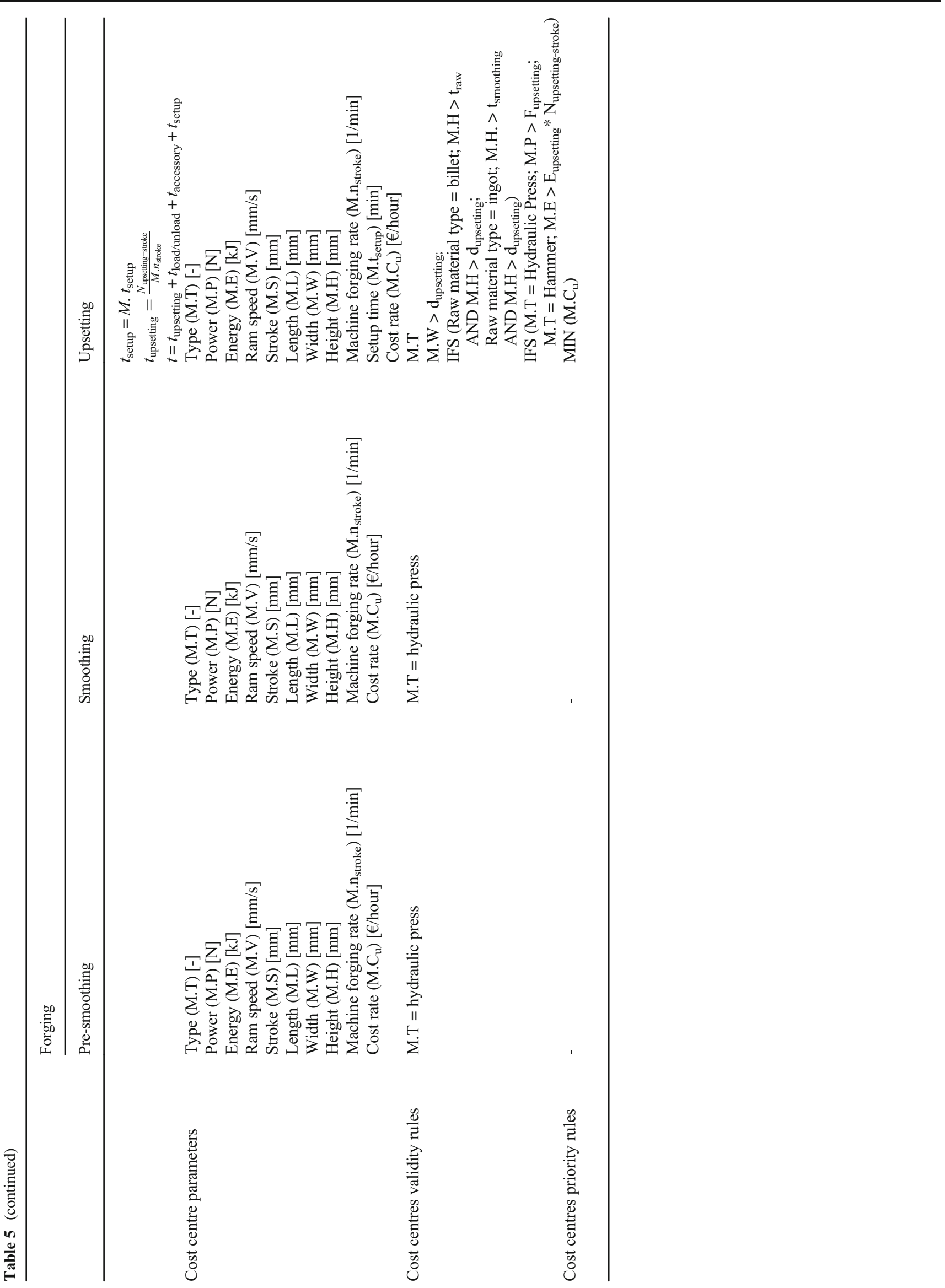


The accessory time $\left(t_{\text {accessory }}\right)$ is the time required to rechange the die from circular to rectangular.

The quantity of strokes required for cogging operation ( $\left.N_{\text {max-shoulder-stroke }}\right)$ depends on the part length at the end of this operation $\left(l_{\text {max-shoulder cogging }}\right)$ and die length $\left(l_{\text {die }}\right)$. The length of the part is a function of volume ( $\left.V_{\text {max-shoulder cogging }}\right)$ and part diameter at the end of the operation $\left(d_{\text {max-shoulder coging }}\right)$ (Table 4). This latter is generally indicated within the technical draft of the part.

The other geometric cost drivers (Table 5) for maxshoulder forming are the same ones of the previous operation and are related to part to be formed (material $M$, billet diameter $d_{\text {raw }}$, ingot small diameter $d_{\text {raw }}$, ingot large diameter $D_{\text {raw }}$, billet/ingot length $l_{\text {raw }}$ and weight $W$ ).

\subsubsection{Necking cost}

The necking is an operation that is carried out after maxshoulder forming, using a press composed of a die with a built-in blade. In this phase, the part is notched in correspondence of the diameter variation. The functionality of these notches is to create reference sections for the subsequent forming of other shoulders, approaching to the final shape of the part.

$C_{\text {necking }}=t \cdot M \cdot C_{u}=\left(t_{\text {necking }}+t_{\text {accessory }}+t_{\text {load } / \text { unload }}\right) \cdot M \cdot C_{u}(10)$

Necking time ( $\left.t_{\text {necking }}\right)$ is calculated in the same manner as for previous operations (ratio between the number of strokes required for operation $\left(N_{\text {necking-stroke }}\right)$ and machine stroke rate $\left.\left(M . n_{\text {stroke }}\right)\right)$.

The accessory time $\left(t_{\text {accessory }}\right)$ is the time required to switch from rectangular die to bladed die. The quantity of strokes required for necking operation $\left(N_{\text {necking-stroke }}\right)$ is a function of part diameter $\left(d_{\text {max-shoulder cogging }}\right)$, and the number of shoulders $\left(N_{\text {shoulder }}\right)$. According to a study conducted at some forge masters, this quantity lies between 10 and 16. The geometric cost drivers (Table 6) for necking are the same of the previous operation and are related to the raw material to be formed (material $M$, billet diameter $d_{\text {raw }}$, ingot small diameter $d_{\text {raw }}$, ingot large diameter $D_{\text {raw }}$, billet/ingot length $l_{\text {raw }}$ and weight $W$ ).

\subsubsection{Shoulders cogging cost}

This operation allows obtaining the final shape of the piece. Cogging cost for other shoulder is calculated in the same manner as the max-shoulder cogging cost with a difference in the number of strokes required for each shoulder, which depends on the shoulder length $\left(l_{\text {shoulder- } n}\right)$, the die length $\left(l_{\text {die }}\right)$ and the die usage $\left(f_{\text {die }}\right)$.
The cost of shoulder cogging operation $\left(C_{\text {shoulder cogging }}\right)$ is calculated in this way.

$$
\begin{aligned}
& C_{\text {shoulder cogging }}=t \cdot M \cdot C_{u} \\
& \quad=\left(t_{\text {shoulder cogging }}+t_{\text {accessory }}+t_{\text {load } / \text { unload }}\right) \cdot M \cdot C_{u}
\end{aligned}
$$

The accessory time $t_{\text {accessory }}$ is the time required to switch from bladed die to rectangular die. The time required for forging the shoulders $\left(t_{\text {shoulder cogging }}\right)$ is the sum of single times $\left(t_{\text {shoulder cogging-n }}\right)$ required for forging the n-shoulder. Each nshoulder time $\left(t_{\text {shoulder cogging-n }}\right)$ is the ratio between $\mathrm{n}$-shoulder stroke required ( $\left.N_{\text {shoulder-n cogging-stroke }}\right)$ and machine forging rate $\left(M . n_{\text {stroke }}\right)$. The geometric cost drivers (Table 5) for cogging are the same of the previous operation, and they are related to raw material to be formed (material $M$, ingot small diameter $d_{\text {raw }}$, ingot large diameter $D_{\text {raw }}$, ingot length $l_{\text {raw }}$ and weight $W$ ).

\section{Case study}

The cost model presented in the previous section allows design engineers to evaluate manufacturing cost of open dieforged axisymmetric components. Cost accuracy, according to a survey carried out on several companies designing open-die forged components, should range between -15 and $+15 \%$. Cost accuracy should be higher when cost estimation methods are used during product engineering. Here, manufacturing cost can be used, for example, as a baseline for the supplier's negotiation (the higher the accuracy, the higher the procurement yield). Hence, the goal of the case study is to evaluate the accuracy of the proposed cost model.

The test has been carried out in cooperation with a company that designs turbomachines. This test refers to two essential kinds of components of an axial compressor (Fig. 4): (i) rotating round discs (blades are fixed at their periphery) and (ii) the main shaft (element connecting all the round discs).

Beyond this company, the test involved two qualified forge masters, since the company completely outsources the die forging process of such components. Suppliers were selected considering their annual turnover and quality certification. Each supplier selected a cost engineer in charge to retrieve data required for this test. Workshops of these companies consist of hydraulic presses, mechanical hammers with electromechanical drive, without sensors for monitoring energy consumption and other process parameters.

Once established the companies involved in the test, a workshop with researchers (the authors of the paper) and cost engineers (employers from the involved companies) has been arranged. During the workshop researchers presented the costs model and the related information to the cost engineers 


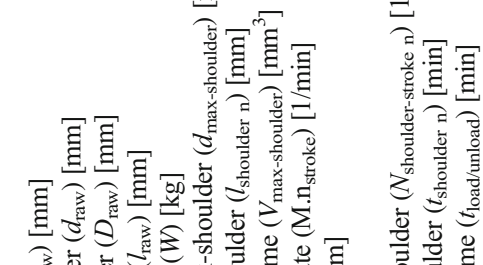

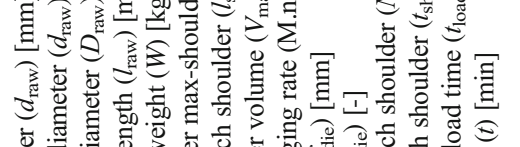

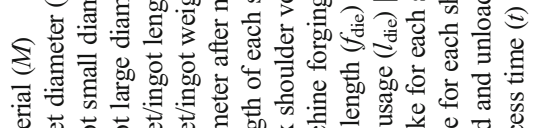

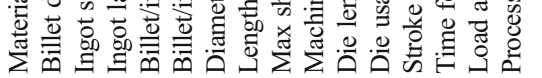

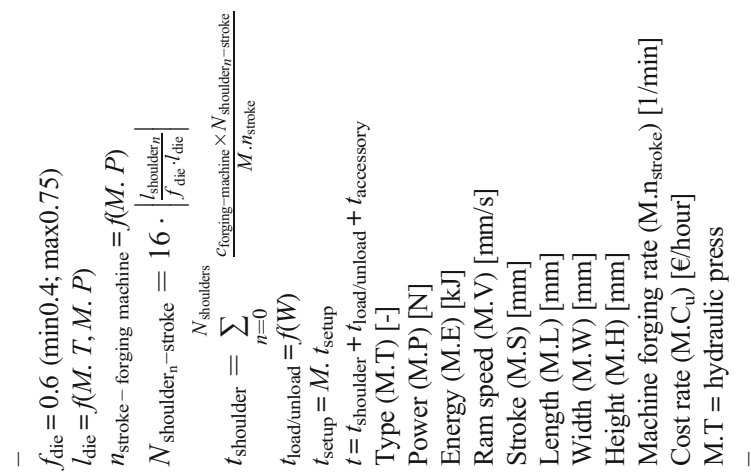

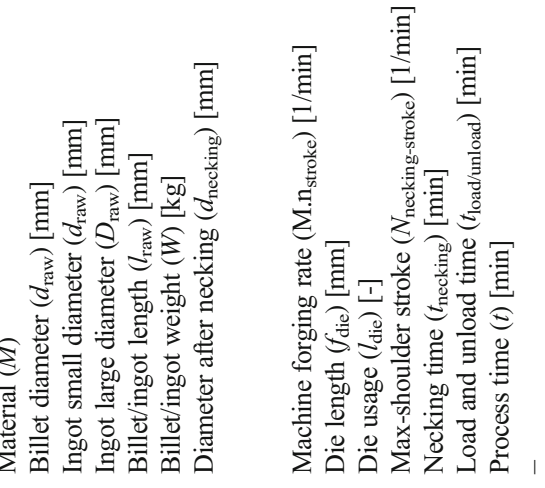

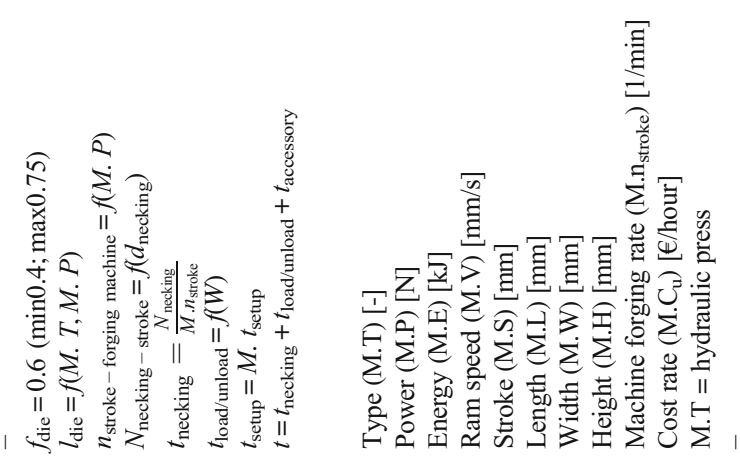

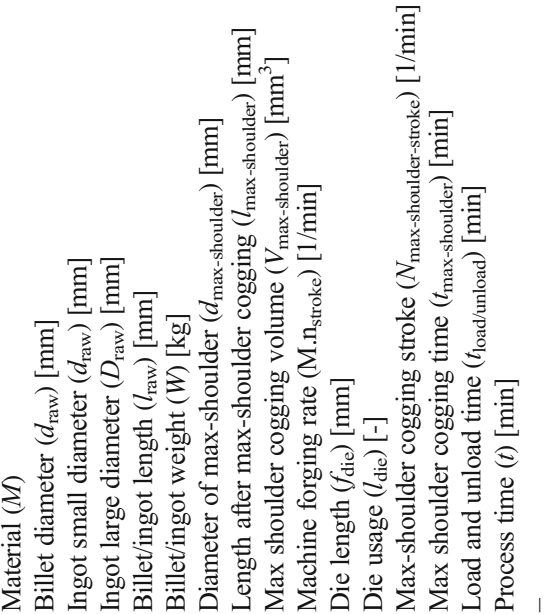
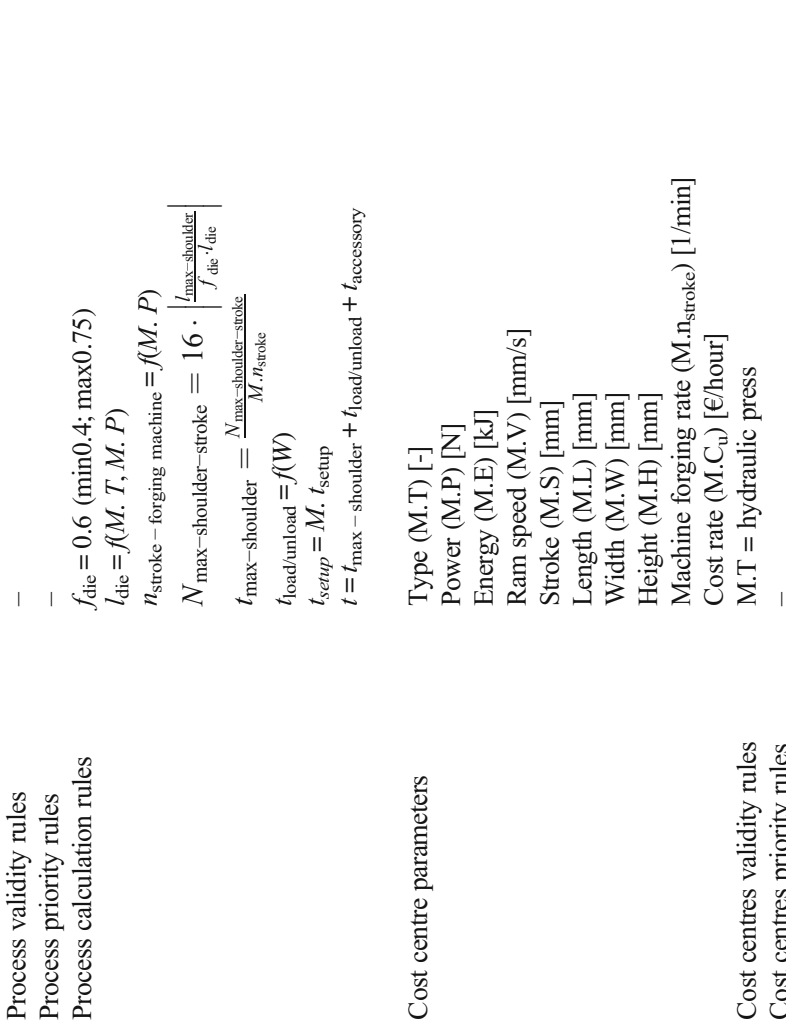

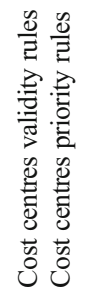


Fig. 4 Two examples of the cylindrical disc (a) and shaft (b) used for the testing (figures refer to disc and shaft after turning). (C) 2020 Baker Hughes Company. All rights reserved
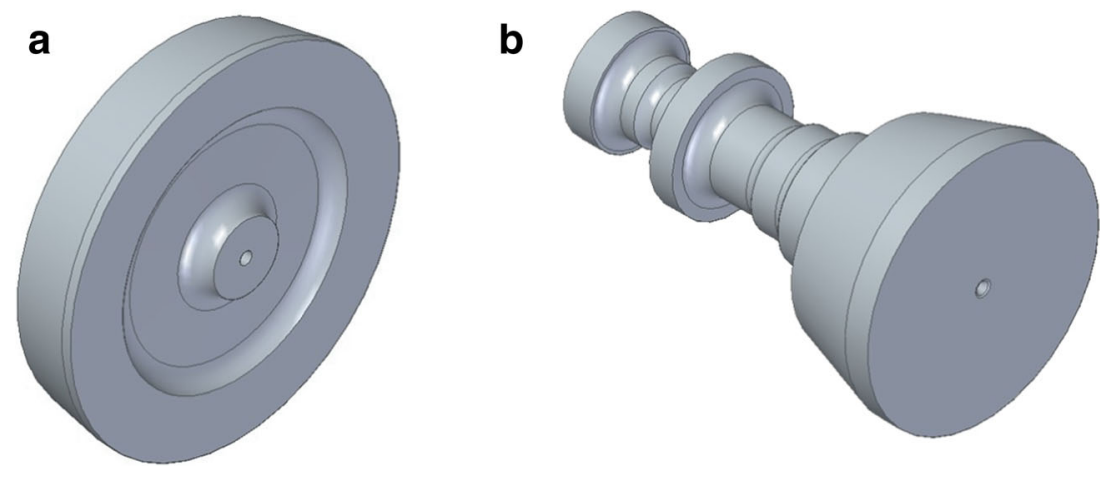

involved in this phase. The cost model has been integrated within a commercial software tool for manufacturing cost estimation (namely, LeanCOST, by Hyperlean Srl). During the workshop, the test methodology has been defined. The test has been performed on two round discs and six shafts, different for material, size and shape, realised in batches from two to four (Table 7). Data stored within raw material (i.e. billet sizes and unitary cost), materials (i.e. mechanical, thermal and physical properties) and cost centres (i.e. presses, band saw machines and furnaces, with relative parameters) databases have been set according to the facilities of the involved production companies. Such hypotheses were required for evaluating the reliability of the proposed cost model (e.g. rules, process parameters) independently by other factors (e.g. production country).

Tests have been carried out by researchers for all the selected components. For this aim, researchers used LeanCOST with embedded the here presented open-die forging cost model. The raw material for each component was manually designed using a 3D CAD software tool, according to the procedure presented in Section 2.1.1. The estimated process parameters and total cost (automatically computed according to the rules and data available within the databases) have been considered as the set of test data to be compared with the corresponding ones gathered from the involved companies.

\section{Results and discussion}

Results collected during the case study were stored in Table 8. It contains the meaningful information required for evaluating the analytical model for the cost estimation of axisymmetric components realised with open die-forging processes. Such values are raw material and manufacturing cost, and they are respectively used for evaluating the cost model reliability in estimating the forged raw material and the manufacturing process (cutting, heating and forging) cost. Table 8 contains estimated and actual values, which are respectively those values computed by using the proposed cost model and got from the forge masters. Actual values have been provided by the cost engineers of the forge masters.

The raw material costs were attributed according to the weight of billets used by the forge masters. The manufacturing costs were computed measuring the processing and set-up times of the whole process (cutting, heating and forging). For confidentiality reasons, Table 8 contains only agglomerated raw material and manufacturing costs. Then, the arithmetic (Dev.) and absolute (Abs. dev.) average deviations between estimated (Est.) and actual (Act.) values have been measured. At last, the average and standard deviation (last two columns on the right of Table 8) for raw material cost, manufacturing cost and total cost have been evaluated to establish the goodness of the proposed cost model. The absolute average deviation is that parameter to be compared with the threshold presented in Section $3( \pm 15 \%)$ for evaluating the cost model accuracy. Cost values are dimensionless for confidentiality reason (costs were multiplied by a fixed scaling factor).

The analysis of the previous table allows authors to highlight the high reliability of the algorithm for estimating the raw material volume (Section 2.1.1) and the billet dimensions (Section 2.1.2). The average absolute deviation between the estimated and actual billet weight is $3.6 \%$ (Fig. 5). This discrepancy is considered a robust result because the raw material is the most critical cost item in forged components, and it is directly calculated by multiplying the unitary cost of material by its weight. The difference in weight between the raw material estimated employing the method proposed in Section 2.1.1 and the same one designed by a design engineer is due by four reasons, to be considered for improving the algorithm:

- Undercuts: forged components, often, do not have undercuts;

- Rounded edges: forged components do not have sharp edges, replace by rounded ones for favouring the material flow;

- Drafted surfaces: surfaces must be drafted for removing the forged component from the die (this is negligible for open-die forging); 
- Differentiated machining allowance: machining allowance could be different for external and internal surfaces.

Concerning the manufacturing cost, it is possible to measure an average absolute deviation of $20.9 \%$, which is higher than $15 \%$ (12\% for discs and $24 \%$ for shafts). The fact that discs have a higher reliability than shafts is mainly due to the simpler shapes of the former. From the results obtained in the case study, it is possible to underline that the material $(M)$ is the most influencing geometric cost driver in the analytical cost model. This outcome is in line with the results obtained by the literature analysis $[28,31]$. The material is directly related to the raw material $\operatorname{cost}\left(C u_{\text {material }}, \rho, S_{\text {scale lost }}\right)$ and indirectly to the manufacturing cost of the forged part. Material cost driver contains the information about the shear stress $\left(Y_{\text {shear }}\right)$, necessary to calculate the shearing force ( $F_{\text {shearing }}$ ), and also the information about the strain rate strength $\left(K^{\prime}\right)$ and the strain rate sensitivity exponent $(m)$, which are needed to calculate the load and energy in upsetting operation ( $\left.F_{\text {upsetting }}, E_{\text {upsetting }}\right)$. From cutting force, load and energy required in operations are selected the machine tonnage and then their unitary costs. Besides, the heating cost is affected by the material, since the forging temperature $\left(T_{f \text { max }}\right.$, $\left.T_{f \text {.min }}\right)$, the heating and cooling time $\left(t_{\text {heating }}, t_{\text {cooling }}\right)$ depend on the material.

Other important geometric cost drivers are the component dimensions and its volume, from which are calculated the raw material cost (Eq. 2). The component dimensions contribute to the attribution of the machine size. Dimensions also affect the manufacturing cost through the force, load, energy ant times required to cut, heat or deform the part. In particular, from the deformation point of view, the most critical dimension is the upsetting diameter ( $d_{\text {upsetting }}$ ), which affects the machine tonnage. For the cutting process, the most significant variable is the billet diameter $\left(d_{\text {raw }}\right)$, which affects the cutting rate ( $\left.R_{\text {cutting }}\right)$ and the shearing force $\left(F_{\text {shearing }}\right)$. Concerning the process cost, the most critical variable is the selected cost centre (press or hammer), since the manufacturing cost is computed as the product between the forging time and the cost centre rate. A cost centre is selected according to the load required for forging a billet or ingot, and the initial upsetting is that phase which requires the highest force.

From the analysed cost drivers and the costs of Table 8, it can be concluded that the correct definition of the material parameters is fundamental for the proposed cost model, also considering the very high raw material share on the total cost (raw material cost ranges fall within 86 to $94 \%$ of the total cost). However, since the average deviation in estimating the manufacturing cost is higher than $15 \%$ (threshold considered acceptable by design engineers), further analyses should be carried for improving the proposed cost model.

Since the error in estimating the cost for discs is lower than shafts, and considering that the most critical phases for forging 
Table 8 Comparison (Dev. and Abs. dev.) between estimated (Est.) and actual (Act.) open die forging cost for eight different forged components. *All the costs are dimensionless for confidentiality reason. (C) 2020 Baker Hughes Company. All rights reserved

\begin{tabular}{|c|c|c|c|c|c|c|c|c|c|c|c|}
\hline Component & & D1 & D2 & $\mathrm{S} 1$ & S2 & $\mathrm{S} 3$ & S4 & S5 & S6 & $\begin{array}{l}\text { Absolute average } \\
\text { deviation }\end{array}$ & Standard deviation \\
\hline \multirow[t]{4}{*}{ Raw material cost* [-] } & Est. & 1229 & 1515 & 1511 & 1041 & 1541 & 1548 & 515 & 722 & & \\
\hline & Act. & 1164 & 1379 & 1506 & 1103 & 1542 & 1547 & 545 & 730 & & \\
\hline & Dev. & $6 \%$ & $10 \%$ & $0 \%$ & $-6 \%$ & $0 \%$ & $0 \%$ & $-6 \%$ & $-1 \%$ & & \\
\hline & Abs. dev. & $6 \%$ & $10 \%$ & $0 \%$ & $6 \%$ & $0 \%$ & $0 \%$ & $6 \%$ & $1 \%$ & $3.6 \%$ & $3.9 \%$ \\
\hline \multirow[t]{4}{*}{ Manufacturing cost* [-] } & Est. & 92 & 106 & 171 & 82 & 118 & 126 & 77 & 69 & & \\
\hline & Act. & 83 & 95 & 155 & 131 & 171 & 152 & 80 & 122 & & \\
\hline & Dev. & $12 \%$ & $12 \%$ & $11 \%$ & $-37 \%$ & $-31 \%$ & $-17 \%$ & $-3 \%$ & $-44 \%$ & & \\
\hline & Abs. dev. & $12 \%$ & $12 \%$ & $11 \%$ & $37 \%$ & $31 \%$ & $17 \%$ & $3 \%$ & $44 \%$ & $20.9 \%$ & $14.6 \%$ \\
\hline \multirow[t]{4}{*}{ Total cost* [-] } & Est. & 1321 & 1620 & 1682 & 1123 & 1659 & 1675 & 592 & 790 & & \\
\hline & Act. & 1246 & 1473 & 1661 & 1234 & 1713 & 1699 & 624 & 853 & & \\
\hline & Dev. & $6 \%$ & $10 \%$ & $1 \%$ & $-9 \%$ & $-3 \%$ & $-1 \%$ & $-5 \%$ & $-7 \%$ & & \\
\hline & Abs. dev. & $6 \%$ & $10 \%$ & $1 \%$ & $9 \%$ & $3 \%$ & $1 \%$ & $5 \%$ & $7 \%$ & $5.3 \%$ & $3.4 \%$ \\
\hline
\end{tabular}

discs are upsetting and max-shoulder cogging, it can be concluded that further improvements must be focused on the following phases:

- Pre-smoothing and smoothing: forging phases employed in case of ingots;

- Necking and other-shoulder cogging: forging phases required for shafts with multiple cylindrical spans.

In conclusion, by evaluating the average absolute deviation on the total cost, it is possible to observe that this value is $5.3 \%$ (less than 15\%), which is a promising result for a novel cost model for open die forging.

\section{Conclusions}

The paper presents an analytical model for cost estimation of axisymmetric components manufactured through open-die forging technology. By using geometrical product information, the model allows providing a detailed cost breakdown considering the overall open-die forging manufacturing process, from the raw material to the forged component. The cost model consists of a set of knowledge for estimating the shape and dimensions of the forged component, required when only the final component shape (that one achieved after machining operations) is known. The second set of knowledge is used for estimating the cost for cutting, heating and forging. Rules and parameters are applicable for axisymmetric components, typical of discs and shafts. The paper contains the complete set of rules and data required for analytical cost estimation in a manner that can be easily replicated using an electronic spreadsheet.

Cost model has been validated in cooperation with two forge masters and a company operating in the Oil \& Gas sector, by considering eight different components employed in a turbomachine. Components have been selected for covering a wide range of dimensions (from around $500 \mathrm{~kg}$ up to 2 tons), different shapes (discs and shafts with multiple cylindrical spans) and materials (carbon and special steels).

The analysis of the deviation between the estimated and actual values allowed to evaluate the reliability of the proposed cost model. The absolute error in estimating the raw material cost is $3.6 \%$ (min value $0 \%$, max value $10 \%$, standard deviation $3.9 \%$ ). It means that the design process for forged shape definition can rigorously estimate the raw material cost (it is advisable only minor improvements). Lower accuracy is observable for that items of the cost model used for manufacturing cost estimation. The absolute deviation is $20.9 \%$ (min value $3 \%$, max value $44 \%$, average deviation $14.6 \%$ ). This set of knowledge requires further improvements,
Fig. 5 Comparison between designed (red) and estimated (green) stock

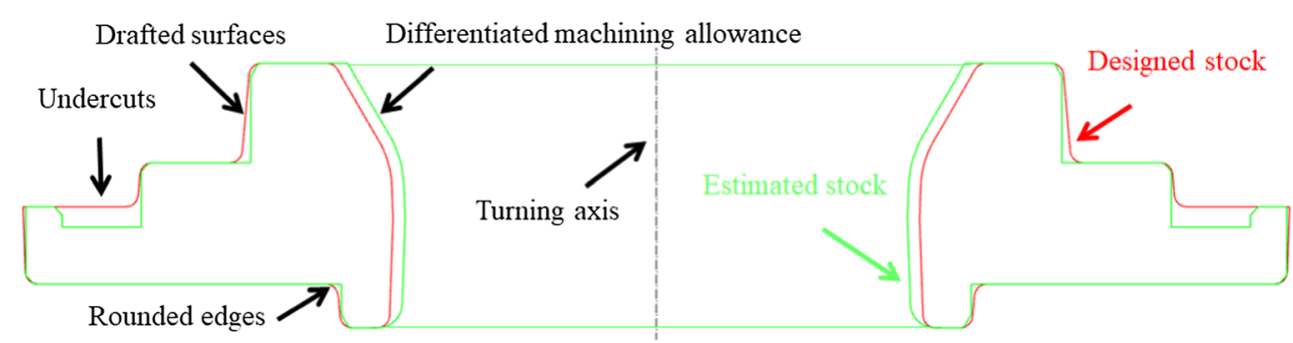


which must be focused mainly on shafts. Indeed, shafts are made by multiple cylindrical spans realised with several forging operations, alternated with handling and heating phases, often carried out employing special equipment (components weight may range from a dozen of kilogrammes to several tons), which are difficult to be estimated before production. Nevertheless, the manufacturing cost share is much lower than raw material one, for which it was possible to appreciate significant reliability of the cost model.

Further improvements will be oriented in improving the algorithms and process parameters for forging and handling very heavy (more than 1 ton) and complex axisymmetric components (more than ten cylindrical spans). Pre-smoothing, smoothing, necking and other-shoulder cogging are those forging phases to be improved in terms of rules and data for cost estimation. It is also necessary to improve the algorithm for generating the raw material shape, that should be adapted to manage hollow shapes (e.g. shafts with axial depressions), hybrid shapes (i.e. round shafts with flat surfaces) and eccentric shapes (i.e. shafts with two or more symmetry axes).

Another future outlook will regard the study of parametric cost models, based on artificial intelligence methods (e.g. bigdata, data-mining), to be used during the preliminary design phases as a sort of conceptual costing. The great challenge will consist in developing reliable parametric cost models based on a limited set of data. Indeed, open-die forging is commonly used for small production volumes.

Funding information Open access funding provided by Università Politecnica delle Marche within the CRUI-CARE Agreement.

\section{Appendix}

Table 9 List of symbols used in the study

\begin{tabular}{|c|c|c|c|}
\hline Acronyms & Name & Description & Unit of measure \\
\hline$\mu$ & Friction coefficient & Friction coefficient between die and forged part & {$[-]$} \\
\hline$C_{\text {cutting }}$ & Cutting cost & Total cost of cutting process & {$[€]$} \\
\hline$C_{\text {forging }}$ & Forging cost & Total cost of forging process & {$[€]$} \\
\hline$C_{\text {heating }}$ & Heating cost & Total cost of heating process & {$[€]$} \\
\hline$C_{\text {material }}$ & Material cost & Total cost of material used & {$[€]$} \\
\hline$C_{\text {max-shoulder cogging }}$ & Max-shoulder cogging cost & $\begin{array}{l}\text { Total cost of process for cogging larger } \\
\text { shoulder }\end{array}$ & {$[€]$} \\
\hline$C_{\text {necking }}$ & Necking cost & Total cost of necking process & {$[€]$} \\
\hline$C_{\text {pre-smoothing }}$ & Pre-smoothing cost & Total cost of pre-smoothing process & {$[€]$} \\
\hline$C_{\text {shoulder cogging }}$ & Shoulder cogging cost & Total cost of process for cogging all shoulders & {$[€]$} \\
\hline$C_{\text {smoothing }}$ & Smoothing cost & Total cost of smoothing process & [€] \\
\hline$C u_{\text {material }}$ & Material unitary cost & Unitary price of virgin material & {$[€ / \mathrm{kg}]$} \\
\hline$C_{\text {upsetting }}$ & Upsetting cost & Total cost of upsetting process & {$[€]$} \\
\hline$C u_{\text {scrap }}$ & Scrap unitary cost & Unitary price of forging scraps & {$[€ / \mathrm{kg}]$} \\
\hline$d_{\text {max-shoulder }}$ & Max-shoulder diameter & Diameter of larger shoulder & {$[\mathrm{mm}]$} \\
\hline$d_{\text {necking }}$ & Necking diameter & Diameter of larger shoulder & {$[\mathrm{mm}]$} \\
\hline$d_{\text {raw }}$ & Billet diameter/ingot small diameter & $\begin{array}{l}\text { Billet diameter or ingot small diameter, based } \\
\text { on the one used }\end{array}$ & {$[\mathrm{mm}]$} \\
\hline$D_{\text {raw }}$ & Ingot large diameter & Diameter of the ingot large part & {$[\mathrm{mm}]$} \\
\hline$d_{\text {shoulder } \mathrm{n}}$ & Shoulder diameter & Diameter of n-shoulder & {$[\mathrm{mm}]$} \\
\hline$d_{\text {smoothing }}$ & Smoothing diameter & $\begin{array}{l}\text { Diameter of the part at the end of smoothing } \\
\text { process }\end{array}$ & {$[\mathrm{mm}]$} \\
\hline$d_{\text {upsetting }}$ & Upsetting diameter & $\begin{array}{l}\text { Diameter of the part at the end of upsetting } \\
\text { process }\end{array}$ & {$[\mathrm{mm}]$} \\
\hline$f_{\text {die }}$ & Die usage & $\begin{array}{l}\text { Percentage of the die width used during } \\
\text { operations }\end{array}$ & {$[\%]$} \\
\hline$F_{\text {shearing }}$ & Shearing force & Force required for shearing the billet & {$[\mathrm{N}]$} \\
\hline$K^{\prime}$ & Strain rate strength & Strain rate strength of material used & {$[\mathrm{MPa}]$} \\
\hline$l_{\text {die }}$ & Die length & $\begin{array}{l}\text { Length of forging machine die used in } \\
\text { operations }\end{array}$ & {$[\mathrm{mm}]$} \\
\hline$l_{\text {max-shoulder }}$ & Max-shoulder length & $\begin{array}{l}\text { Length of the part at the end of max-shoulder } \\
\text { cogging process }\end{array}$ & {$[\mathrm{mm}]$} \\
\hline
\end{tabular}


Table 9 (continued)

\begin{tabular}{|c|c|c|c|}
\hline Acronyms & Name & Description & Unit of measure \\
\hline$l_{\text {necking }}$ & Necking length & Length of the part at the end of necking process & {$[\mathrm{mm}]$} \\
\hline$l_{\text {raw }}$ & Billet length/ingot length & $\begin{array}{l}\text { Billet length or ingot length, based on the one } \\
\text { used }\end{array}$ & {$[\mathrm{mm}]$} \\
\hline$l_{\text {raw }} / \mathrm{d}_{\text {raw }}$ & Slenderness factor & Ratio between billet length and billet diameter & {$[-]$} \\
\hline$l_{\text {shoulder } \mathrm{n}}$ & Shoulder length & $\begin{array}{l}\text { Length of the n-shoulder sector at the end of the } \\
\text { process }\end{array}$ & {$[\mathrm{mm}]$} \\
\hline$l_{\text {smoothing }}$ & Smoothing length & $\begin{array}{l}\text { Length of the part at the end of smoothing } \\
\text { process }\end{array}$ & {$[\mathrm{mm}]$} \\
\hline$l_{\text {upsetting }}$ & Upsetting length & $\begin{array}{l}\text { Length of the part at the end of upsetting } \\
\text { process }\end{array}$ & {$[\mathrm{mm}]$} \\
\hline$M$ & Material type & Type of material used & {$[-]$} \\
\hline$m$ & Strain rate sensitivity exponent & Strain rate sensitivity exponent of material used & {$[-]$} \\
\hline M. $C_{u}$ & Machine or furnace hourly rate & $\begin{array}{l}\text { Unitary cost of cutting machine or heating } \\
\text { furnace or machine used in forging } \\
\text { operations }\end{array}$ & {$[€ / \mathrm{min}]$} \\
\hline M.E & Machine energy & $\begin{array}{l}\text { Energy of shearing machine or energy of } \\
\text { machine used in forging operations }\end{array}$ & {$[\mathrm{kJ}]$} \\
\hline M.H & Furnace or machine height & $\begin{array}{l}\text { Internal height of furnace or height of working } \\
\text { area of forging machine }\end{array}$ & {$[\mathrm{mm}]$} \\
\hline M. $H_{\text {width }}$ & Machine head width & Head width of shearing machine & {$[\mathrm{mm}]$} \\
\hline M.L & Furnace or machine length & $\begin{array}{l}\text { Internal length of furnace or length of working } \\
\text { area of forging machine }\end{array}$ & {$[\mathrm{mm}]$} \\
\hline$M . n_{\text {stroke }}$ & Machine forging rate & $\begin{array}{l}\text { Number of strokes per minute of shearing } \\
\text { machine or }\end{array}$ & {$\left[\mathrm{min}^{-1}\right]$} \\
\hline$M . n_{\text {stroke }}$ & Machine forging rate & $\begin{array}{l}\text { Number of strokes per minute of forging } \\
\text { machine }\end{array}$ & {$\left[\mathrm{min}^{-1}\right]$} \\
\hline M.P & Machine power & $\begin{array}{l}\text { Power of shearing machine or machine used in } \\
\text { forging operations }\end{array}$ & {$[\mathrm{N}]$} \\
\hline M.S & Machine stroke & $\begin{array}{l}\text { Distance between the top and bottom dead } \\
\text { centres of the ram }\end{array}$ & {$[\mathrm{mm}]$} \\
\hline M.Sp & Machine speed & Speed of sawing machine & {$[\mathrm{m} / \mathrm{min}]$} \\
\hline M.T & Machine type & $\begin{array}{l}\text { Choose between hammers or hydraulic presses } \\
\text { for shearing and hinge or double column } \\
\text { types for sawing and hammer or press for } \\
\text { forging operations }\end{array}$ & {$[-]$} \\
\hline M.V & Machine ram speed & Drop speed of machine ram & {$[\mathrm{mm} / \mathrm{s}]$} \\
\hline$M . W$ & Machine width & $\begin{array}{l}\text { Width of working area of shearing or sawing } \\
\text { machine, or internal width of furnace or } \\
\text { width of working area of forging machine }\end{array}$ & {$[\mathrm{mm}]$} \\
\hline$N_{\text {max-shoulder -stroke }}$ & Max-shoulder cogging stroke & $\begin{array}{l}\text { Number of strokes required for max-shoulder } \\
\text { cogging operation }\end{array}$ & {$[-]$} \\
\hline$N_{\text {necking }}$ & Necking stroke & $\begin{array}{l}\text { Number of strokes required for necking } \\
\text { operation }\end{array}$ & {$[-]$} \\
\hline$N_{\text {re-heat }}$ & Re-heats number & Number of reheats required & {$[-]$} \\
\hline$N_{\text {shoulder-n stroke }}$ & Shoulder stroke & $\begin{array}{l}\text { Number of strokes required for } \mathrm{n} \text {-shoulder } \\
\text { operation }\end{array}$ & {$[-]$} \\
\hline$N_{\text {smoothing-stroke }}$ & Smoothing stroke & $\begin{array}{l}\text { Number of strokes required for smoothing } \\
\text { operation }\end{array}$ & {$[-]$} \\
\hline$N_{\text {upsetting-stroke }}$ & Upsetting stroke & $\begin{array}{l}\text { Number of strokes required for upsetting } \\
\text { operation }\end{array}$ & {$[-]$} \\
\hline$P_{b}$ & Production batch & Production batch quantity & {$[-]$} \\
\hline$Q_{a}$ & Friction multiplying factor & Friction multiplying factor between die and part & {$[-]$} \\
\hline$R_{\text {cutting }}$ & Cutting rate & Sawing machine cutting rate & {$\left[\mathrm{mm}^{2} / \mathrm{min}\right]$} \\
\hline$S_{\text {scale lost }}$ & Scale loss factor & Material scale loss factor caused by heating & {$[\%]$} \\
\hline$t$ & Process time & Total time required for a process & {$[\mathrm{min}]$} \\
\hline$t_{\text {accessory }}$ & Accessory time & Time required for accessory operations & {$[\mathrm{min}]$} \\
\hline$t_{\text {cooling }}$ & Cooling time & & {$[\mathrm{min}]$} \\
\hline
\end{tabular}


Table 9 (continued)

\begin{tabular}{|c|c|c|c|}
\hline Acronyms & Name & Description & Unit of measure \\
\hline & & $\begin{array}{l}\text { Time required to achieve Min forging } \\
\text { temperature starting from Max forging } \\
\text { temperature }\end{array}$ & \\
\hline$t_{\text {cutting }}$ & Cutting time & Time required for cutting operation & {$[\mathrm{min}]$} \\
\hline$T_{f \cdot \max }$ & Max forging temperature & $\begin{array}{l}\text { Forging temperature upper limit beyond which } \\
\text { could be generated cracking in forged part }\end{array}$ & {$\left[{ }^{\circ} \mathrm{C}\right]$} \\
\hline$T_{f \cdot \min }$ & Min forging temperature & $\begin{array}{l}\text { Forging temperature lower limit under which } \\
\text { the force to deform the forged part is too high }\end{array}$ & {$\left[{ }^{\circ} \mathrm{C}\right]$} \\
\hline$t_{\text {heating }}$ & Heating time & Time required for heating operation & {$[\mathrm{min}]$} \\
\hline$t_{\text {load/unload }}$ & Load and unload time & Time required for load and unload operation & {$[\mathrm{min}]$} \\
\hline$t_{\text {max-shoulder cogging }}$ & Max-shoulder cogging time & $\begin{array}{l}\text { Time required for max-shoulder cogging } \\
\text { operation }\end{array}$ & {$[\mathrm{min}]$} \\
\hline$t_{\text {necking }}$ & Necking time & Time required for necking operation & {$[\mathrm{min}]$} \\
\hline$t_{\text {pre-smoothing }}$ & Pre-smoothing time & Time required for pre-smoothing operation & {$[\mathrm{min}]$} \\
\hline$t_{\text {re-heating }}$ & Reheating time & Time required for reheating operation & {$[\mathrm{min}]$} \\
\hline$T_{s}$ & Shearing temperature & Temperature at which the shear takes place & {$\left[{ }^{\circ} \mathrm{C}\right]$} \\
\hline$t_{\text {setup }}$ & Set-up time & Time required for set-up operation & {$[\mathrm{min}$} \\
\hline$t_{\text {shoulder cogging }}$ & Shoulder cogging time & Time required for cogging operation & {$[\mathrm{min}]$} \\
\hline$t_{\text {smoothing }}$ & Smoothing time & Time required for smoothing operation & {$[\mathrm{min}]$} \\
\hline$t_{\text {upsetting }}$ & Upsetting time & Time required for upsetting operation & {$[\mathrm{min}]$} \\
\hline$V_{\text {forged }}$ & Forged volume & $\begin{array}{l}\text { Volume of material required for the forging } \\
\text { process }\end{array}$ & {$\left[\mathrm{dm}^{3}\right]$} \\
\hline$V_{\text {max-shoulder }}$ & Max-shoulder volume & $\begin{array}{l}\text { Volume of the part at the end of max-shoulder } \\
\text { cogging process }\end{array}$ & {$\left[\mathrm{dm}^{3}\right]$} \\
\hline$V_{\text {necking }}$ & Necking volume & Volume of the part at the end of necking process & {$\left[\mathrm{dm}^{3}\right]$} \\
\hline$V_{\text {pre-smoothing }}$ & Pre-smoothing volume & $\begin{array}{l}\text { Volume of the part at the end of pre-smoothing } \\
\text { process }\end{array}$ & {$\left[\mathrm{dm}^{3}\right]$} \\
\hline$V_{\text {scrap }}$ & Scrap volume & Scrap volume that can be recovered and resold & {$\left[\mathrm{dm}^{3}\right]$} \\
\hline$V_{\text {shoulder-n }}$ & Shoulder volume & $\begin{array}{l}\text { Volume of the n-shoulder sector at the end of } \\
\text { process }\end{array}$ & {$\left[\mathrm{dm}^{3}\right]$} \\
\hline$V_{\text {smoothing }}$ & Smoothing volume & $\begin{array}{l}\text { Volume of the part at the end of smoothing } \\
\text { process }\end{array}$ & {$\left[\mathrm{dm}^{3}\right]$} \\
\hline$V_{\text {stock }}$ & Raw material volume & $\begin{array}{l}\text { Volume of billet or custom ingot, based on the } \\
\text { one used }\end{array}$ & {$\left[\mathrm{dm}^{3}\right]$} \\
\hline$V_{\text {upsetting }}$ & Upsetting volume & $\begin{array}{l}\text { Volume of the part at the end of upsetting } \\
\text { process }\end{array}$ & {$\left[\mathrm{dm}^{3}\right]$} \\
\hline$W$ & Billet/ingot weight & $\begin{array}{l}\text { Weight of the billet or ingot, based on the one } \\
\text { used }\end{array}$ & {$[\mathrm{kg}]$} \\
\hline$w_{\text {die }}$ & Die width & $\begin{array}{l}\text { Width of forging machine die used in } \\
\text { operations }\end{array}$ & {$[\mathrm{mm}]$} \\
\hline$Y_{\text {shearing }}$ & Shear stress & Equivalent material shear stress & {$[\mathrm{MPa}]$} \\
\hline$\varepsilon$ & Strain & Strain rate of material used & {$[-]$} \\
\hline$\xi$ & Strain rate & Strain rate of material used & {$[1 / \mathrm{s}]$} \\
\hline$\rho$ & Material density & Density of material used & {$\left[\mathrm{kg} / \mathrm{dm}^{3}\right]$} \\
\hline
\end{tabular}


Open Access This article is licensed under a Creative Commons Attribution 4.0 International License, which permits use, sharing, adaptation, distribution and reproduction in any medium or format, as long as you give appropriate credit to the original author(s) and the source, provide a link to the Creative Commons licence, and indicate if changes were made. The images or other third party material in this article are included in the article's Creative Commons licence, unless indicated otherwise in a credit line to the material. If material is not included in the article's Creative Commons licence and your intended use is not permitted by statutory regulation or exceeds the permitted use, you will need to obtain permission directly from the copyright holder. To view a copy of this licence, visit http://creativecommons.org/licenses/by/4.0/.

\section{References}

1. Altan T, Ngaile G, Shen G (2005) Cold and hot forging: fundamentals and applications. ASM International

2. Arundacahawat A, Roy R, Al-Ashaab A (2013) An analogy based estimation framework for design rework efforts. J Intell Manuf 24: 625-639. https://doi.org/10.1007/s10845-011-0605-6

3. Bariani PF, Berti G (1993) D'Angelo L (1993) Tool cost estimating at the early stages of cold forging process design. CIRP Ann 42(1): 279-282. https://doi.org/10.1016/S0007-8506(07)62443-3

4. Beddoes J, Bibby M (1999) Principles of metal manufacturing processes. Elsevier, Burlington

5. Berlioz M, Marin P, Tichkiewitch S (1999) A fast and reliable costestimation tool for hot-forged parts. Integrated Des Manuf Mech Eng:595-602. https://doi.org/10.1007/978-94-015-9198-0_73

6. Biswas SK, Knight WA (1976) Towards an integrated design and production system for hot forging dies. Int J Prod Res 14(1):23-49. https://doi.org/10.1080/00207547608956578

7. Boothroyd G, Dewhurst P, Knight WA (2011) Product design for manufacture and assembly, 3rd edn. CRC Press

8. Boothroyd G, Radovanovic P (1989) Estimating the cost of machined components during the conceptual design of a product. CIRP Ann 38(1):157-160. https://doi.org/10.1016/S0007$8506(07) 62674-2$

9. Chiadamrong $\mathrm{N}$ (2003) The development of an economic quality cost model. Total Qual Manag Bus Excell 14(9):999-1014. https:// doi.org/10.1080/1478336032000090914

10. Chou JS, Tai Y (2010) Chang LJ (2010) Predicting the development cost of TFT-LCD manufacturing equipment with artificial intelligence models. Int J Prod Econ 128:339-350. https://doi.org/ 10.1016/j.ijpe.2010.07.031

11. Chougule RG, Ravi B (2006) Casting cost estimation in an integrated product and process design environment. Int J Comput Integr Manuf 19(7):676-688. https://doi.org/10.1080/ 09511920500324605

12. Drozda T (1983) Tool and manufacturing engineers handbook, vol 1: Machining, 4th edn. Society of Manufacturing Engineers

13. Elmousalami HH (2020) Artificial intelligence and parametric construction cost estimate modeling: state-of-the-art review. J Constr Eng Manag 146(1):03119008. https://doi.org/10.1061/(ASCE)CO. 1943-7862.0001678

14. Elmousalami HH (2020) Comparison of artificial intelligence techniques for project conceptual cost prediction: a case study and comparative analysis. In: IEEE Transactions on Engineering Management. https://doi.org/10.1109/TEM.2020.2972078

15. Fagade A, Kazmer D (2003) Early cost estimation of injection molded components. J Injection Molding Technol 4(3)

16. Favi C, Germani M, Mandolini M (2016) Design for manufacturing and assembly vs. design to cost: toward a multi-objective approach for decision-making strategies during conceptual design of complex products. Procedia CIRP 50:275-280. https://doi.org/10.1016/j. procir.2016.04.190

17. Favi C, Germani M, Mandolini M (2017) Analytical cost estimation model in high pressure die casting. Procedia Manuf 11:526-535. https://doi.org/10.1016/j.promfg.2017.07.146

18. Favi C, Germani M, Mandolini M (2018) Development of complex products and production strategies using a multi-objective conceptual design approach. Int J Adv Manuf Technol 95(1-4):12811291. https://doi.org/10.1007/s00170-017-1321-y

19. Favi C, Germani M, Mandolini M (2016) A multi-objective design approach to include material, manufacturing and assembly costs in the early design phase. Procedia CIRP 52:251-256. https://doi.org/ 10.1016/j.procir.2016.07.043

20. García-Crespo A, Ruiz-Mezcua B, López-Cuadrado JL, GonzálezCarrasco I (2011) A review of conventional and knowledge based systems for machining price quotation. J Intell Manuf 22:823-841. https://doi.org/10.1007/s10845-009-0335-1

21. Germani M, Cicconi P, Mandolini M (2011) Manufacturing cost estimation during early phases of machine design. Proceedings of the 18th International Conference on Engineering Design (ICED 11).

22. Hegazy T (1998) Neural network model for parametric cost estimation of highway projects. J Constr Eng Manag 24(3):210-218. https://doi.org/10.1061/(ASCE)0733-9364(1998)124:3(210)

23. H'mida F, Martin P, Vernadat F (2006) Cost estimation in mechanical production: The Cost Entity approach applied to integrated product engineering. Int J Prod Econ 103(1):17-35. https://doi. org/10.1016/j.ijpe.2005.02.016

24. Hihn J, Menzies T (2015) Data mining methods and cost estimation models. Why is it so hard to infuse new ideas? 2015 30th IEEE/ACM International Conference on Automated Software Engineering Workshop (ASEW), Lincoln, NE, 2015, pp. 5-9, https://doi.org/10.1109/ASEW.2015.27.

25. Hoque ASM, Halder PK, Parvez MS, Szecsi T (2013) Integrated manufacturing features and Design-for-manufacture guidelines for reducing product cost under $\mathrm{CAD} / \mathrm{CAM}$ environment. Comput Ind Eng 66(4):988-1003. https://doi.org/10.1016/j.cie.2013.08.016

26. Loyer J-L, Henriques E, Fontul M, Wiseall S (2016) Comparison of machine learning methods applied to the estimation of manufacturing cost of jet engine components. Int J Prod Econ 178:109-116. https://doi.org/10.1016/j.ijpe.2016.05.006

27. Kalpakjian S, Schmid S (2017) Manufacturing processes for engineering materials, 6th Edition, Pearson

28. Knight WA (1992) Simplified early cost estimating for hot-forged parts. Int J Adv Manuf Technol 7(3):159-167. https://doi.org/10. 1007/BF02601619

29. Kukhar V, Balalayeva E, Hurkovska S, Sahirov Y, Markov O, Prysiazhnyi A, Anishchenko O (2020) The selection of options for closed-die forging of complex parts using computer simulation by the criteria of material savings and minimum forging force. Intelligent Communication, Control and Devices, Advances in Intelligent Systems and Computing 989. 325-331. https://doi.org/ 10.1007/978-981-13-8618-3_35

30. Łukaszek-Sołek A, Chyła P, Bednarek S (2015) Forging of gas turbine shaft - numerical modelling of technological process. Metal 2015

31. Masel DT, Young WA, Judd RD (2010) A rule-based approach to predict forging volume for cost estimation during product design. Int J Adv Manuf Technol 46(1-4):31-41. https://doi.org/10.1007/ s00170-009-2108-6

32. Mandolini M, Campi F, Favi C, Germani M, Raffaeli R (2020) A framework for analytical cost estimation of mechanical components based on manufacturing knowledge representation. Int $\mathrm{J}$ Adv Manuf Technol 107(3-4):1131-1151. https://doi.org/10.1007/ s00170-020-05068-5 
33. Mauchand M, Siadat A, Bernard A, Perry N (2008) Proposal for tool-based method of product cost estimation during conceptual design. J Eng Des 19(2):159-172. https://doi.org/10.1080/ 09544820701802857

34. Markov OE, Aliiev I, Aliieva L, Hrudkina N (2020) Computerized and physical modeling of upsetting operation by combined dies. Journal of chemical technology and metallurgy 55(3):640-648 https://dl.uctm.edu/journal/node/j2020-3/23 19-275 p 640-648. pdf

35. Markov OE, Perig AV, Zlygoriev VN, Markova MA, Grin AG (2017) A new process for forging shafts with convex dies. Research into the stressed state. Int J Adv Manuf Technol 90: 801-818. https://doi.org/10.1007/s00170-016-9378-6

36. Markov OE, Gerasimenko OV, Shapoval AA, Abdulov OR, Zhytnikov RU (2019) Computerised simulation of shortened ingots with a controlled crystallisation for manufacturing of high-quality forgings. Int J Adv Manuf Technol 103:3057-3065. https://doi.org/ 10.1007/s00170-019-03749-4

37. Niazi A, Dai JS, Balabani S, Seneviratne L (2005) Product cost estimation: technique classification and methodology review. J Manuf Sci Eng 128(2):563-575. https://doi.org/10.1115/1. 2137750

38. Pahl G, Beitz W, Feldhusen J, Grote KH (2007) Engineering design: a systematic approach. 3rd ed., Springer

39. Semiatin SL (2005) ASM Handbook Volume 14A: Metalworking: bulk forming. ASM International
40. Skubisz P, Lisiecki $Ł$, Sińczak J (2015) Studies of the quality and cost-effectiveness of a novel concept of open-die forged powerplant main shaft. Metalurgija 54(2):339-342

41. Ulrich KT, Eppinger SD (2003) Product design and development, 3rd edn. USA, McGraw-Hill Inc

42. Verlinden B, Duflou JR, Collin P, Cattrysse D (2008) Cost estimation for sheet metal parts using multiple regression and artificial neural networks: a case study. Int J Prod Econ 111(2):484-492. https://doi.org/10.1016/j.ijpe.2007.02.004

43. Wang HS (2007) Application of BPN with feature-based models on cost estimation of plastic injection products. Comput Ind Eng 53(1): 79-94. https://doi.org/10.1016/j.cie.2007.04.005

44. Watson P, Curran R, Murphy A, Cowan S (2006) Cost estimation of machined parts within an aerospace supply chain. CE: Research and Applications 14(1):17-26. https://doi.org/10.1177/ 1063293 X06063424

45. Xu X, Fang S, Gu X (2006) A model for manufacturing cost estimation based on machining feature. International Technology and Innovation Conference (ITIC 2006).

46. Xu Y, Elgh F, Erkoyuncu JA, Bankole O, Goh Y, Cheung WM, Baguley P, Wang Q, Arundachawat P, Shehab E, Newnes L, Roy R (2012) Cost engineering for manufacturing: current and future research. Int J Comput Integr Manuf 25(4-5):300-314. https://doi. org/10.1080/0951192X.2010.542183

Publisher's note Springer Nature remains neutral with regard to jurisdictional claims in published maps and institutional affiliations. 